\title{
Breast Cancer Tumor Stroma: Cellular Components, Phenotypic Heterogeneity, Intercellular Communication, Prognostic Implications and Therapeutic Opportunities
}

\author{
Noemi Eiro ${ }^{1, *}$, Luis O. Gonzalez ${ }^{2}$, María Fraile ${ }^{1}$, Sandra Cid ${ }^{1}$, Jose Schneider ${ }^{3}$ and \\ Francisco J. Vizoso 1,4,*iD \\ 1 Research Unit, Fundación Hospital de Jove, Avda. Eduardo Castro, 161, 33290 Gijón, Spain; \\ investigacion@hospitaldejove.com (M.F. \& S.C.) \\ 2 Department of Anatomical Pathology, Fundación Hospital de Jove, Avda. Eduardo Castro, 161, 33290 Gijón, \\ Spain; a.patologica2@hospitaldejove.com \\ 3 Department of Obstetrics and Gynecology, Universidad Rey Juan Carlos, Avda. de Atenas s/n, \\ 28922 Alcorcón, Madrid, Spain; jose.schneider@urjc.es \\ 4 Department of Surgery, Fundación Hospital de Jove, Avda. Eduardo Castro, 161, 33290 Gijón, Spain \\ * Correspondence: noemi.eiro@gmail.com (N.E.); investigacion@hospitaldejove.com (F.J.V.); \\ Tel.: +34-9853-200-50 (N.E. \& F.J.V.)
}

Received: 12 April 2019; Accepted: 8 May 2019; Published: 13 May 2019

\begin{abstract}
Although the mechanisms underlying the genesis and progression of breast cancer are better understood than ever, it is still the most frequent malignant tumor in women and one of the leading causes of cancer death. Therefore, we need to establish new approaches that lead us to better understand the prognosis of this heterogeneous systemic disease and to propose new therapeutic strategies. Cancer is not only a malignant transformation of the epithelial cells merely based on their autonomous or acquired proliferative capacity. Today, data support the concept of cancer as an ecosystem based on a cellular sociology, with diverse components and complex interactions between them. Among the different cell types that make up the stroma, which have a relevant role in the dynamics of tumor/stromal cell interactions, the main ones are cancer associated fibroblasts, endothelial cells, immune cells and mesenchymal stromal cells. Several factors expressed by the stroma of breast carcinomas are associated with the development of metastasis, such as matrix metalloproteases, their tissular inhibitors or some of their regulators like integrins, cytokines or toll-like receptors. Based on the expression of these factors, two types of breast cancer stroma can be proposed with significantly different influence on the prognosis of patients. In addition, there is evidence about the existence of bi-directional signals between cancer cells and tumor stroma cells with prognostic implications, suggesting new therapeutic strategies in breast cancer.
\end{abstract}

Keywords: CAFs; MMPs; TIMPs; cytokines; TLRs; mesenchymal stromal cells; exosomes; integrins

\section{Introduction}

Breast cancer is the most frequent malignant tumor in women and the leading cause of cancer death, since $30 \%$ of breast cancers develop distant metastases after the initial treatment of the apparently localized tumors [1]. Nowadays, the mechanisms underlying the genesis and progression of breast cancer are better understood [2], but despite an improvement of the survival rates for some molecular subtypes of breast cancer, we are still far from a cure for all patients [3]. Furthermore, classical (chemotherapy and radiation therapy) or new therapeutic strategies (selective targeting of 
oncogenes, immune toxicity or oncolytic virotherapy), are far from satisfactory and often associated with significant side effects, including collateral damage, drug resistance, immune toxicity or virus mutability and unexpected toxicity. It seems increasingly clear that the old dogma of cancer based only on a malignant transformation of the epithelial cells is too simplistic, and a new concept considering cancer as an ecosystem based on a cell sociology and the tumor-stroma crosstalk, is gaining strength. A better knowledge of the role of tumor stroma and its interaction with cancer cells can lead us to implement new prognostic tools or new therapeutic strategies aiming at a disruption of the dynamics of tumor-stroma interactions.

In the present work, we reviewed several key pathophysiological aspects related to tumor stroma and breast cancer progression, their clinical implications and possible therapeutic opportunities.

\section{Tumor Stroma Components}

The tumor stroma consists of the non-malignant cells of the tumor mass. Among the various cell types that make up the tumor stroma, and play a key role in tumor-stroma interactions, we mainly find resident cells such as cancer-associated fibroblasts (CAFs), endothelial cells and perycites, blood derived cells such as immune cells, and mesenchymal stroma cells which may be resident or attracted by the tumor itself and sometimes, by adipocytes surrounding it [1].

\subsection{Cancer-Associated Fibroblasts (CAFs)}

Cancer-asssociated-fibroblasts (CAFs) are one of the most abundant cell types in breast cancer stroma with a well recognized role in the initiation and progression of tumor progression. The CAF population derives from resident fibroblasts, but CAFs can also stem from other origins, including mesenchymal stromal cells (MSCs), epithelial cells, pericytes, adipocytes and endothelial cells [2]. CAFs differ from normal fibroblasts by showing a different gene expression profile and promoting cancer cell aggressiveness [3-5].

However, although it has been proposed that contractile forces exerted by CAFs can alter the organization and the physical properties of the basement membrane (interface of epithelium and stroma), making it permissive for cancer cell invasion [6], the role of CAFs in tumor progression is more complex. CAFs show a high proliferation rate and can induce the degradation and remodeling of the extracellular matrix (ECM), epithelial mesenchymal transition (EMT) activation, angiogenic shift, metabolic reprogramming toward a reverse Warburg phenotype, or promote stem cell trait achievement, as compared with normal fibroblasts [7-9]. The influence of CAFs is effected through a paracrine function by means of the secretion of growth factors and cytokines [10-13], such as IL-1 $\beta$, IL-6, IL-8, SDF-1, and NFKB, in order to induce immune cell recruitment that may contribute to tumor progression [14,15]. CAFs are not only able to promote cancer progression but also cancer survival, by means of the creation of a "protective niche" that maintains residual tumor cell survival, such as through the induction of resistance to cancer therapy. In this sense, secretion of hepatocyte growth factor (HGF) and IL-6 by CAFs has been related to lapatinib resistance in HER2+ breast cancer [16] and tamoxifen resistance [17], respectively.

\subsection{Immune Cells}

The immune system plays a complex role in tumorigenesis [18] and immune cells, along with CAFs, are one of the main cell populations making up the tumor mass in invasive breast carcinomas. Tumor-infiltrating leukocytes have been historically considered to be manifestations of an intrinsic defense mechanism against developing tumors [19] and also, subsequently, interpreted as an aborted attempt of the immune system to reject the tumor. However, nowadays, it is well known that leukocyte infiltration can promote tumor growth, angiogenesis and tumor cell invasion [20,21], due to the secretion of cytokines, growth factors, chemokines and proteases [22-24].

The immune cell infiltrate includes a variable representation of leukocytes, including macrophages, neutrophils, mast cells, T- and B-lymphocytes [20]. Breast carcinomas may have different types of 
immune cell infiltrate able to control tumor growth. In this sense, the infiltration of macrophages, also named tumor-associated macrophages (TAMs) and known to have pro-tumoral functions, has been associated with a worse prognosis $[20,25,26]$. Macrophages can be polarized into two phenotypes: classically activated (M1) macrophages and alternatively activated (M2) macrophages driven by a cytokine repertoire of T helper cells (Th1 or Th2). M1 has been established as a tumor-suppressive phenotype and $\mathrm{M} 2$ as a tumor-promoting phenotype, considering that TAMs are primarily M2 polarized. On the other hand, the presence of both $\mathrm{T}$ - and B-cells in the microenvironment has been related to an immunological response, inhibiting cancer development and progression [27-35]. In this sense, a subgroup of $\mathrm{CD}^{+} \mathrm{T}$ helper cells, known as regulatory $\mathrm{T}$ cells (Tregs), has been associated with the suppression of T-cell immunity. Forkhead box protein P3 (FoxP3) is a transcription factor able to induce the immunosuppressive function of Tregs, being the most specific marker for Tregs in tumors. Due to the ability to inhibit anti-tumor immunity, tumor-infiltrating Foxp3+ Tregs were associated with poor prognosis [36], but recently, it has been shown that Foxp3+Tregs could improve survival in some tumors $[37,38]$. In a previous study, we described the clinical relevance of the relative amount of macrophages $\left(\mathrm{CD}^{+} 8^{+}\right)$, T-cells $\left(\mathrm{CD}^{+}\right)$and B-cells $\left(\mathrm{CD} 20^{+}\right)$at the invasive front of breast carcinomas. Thus, an increased CD68 count and CD68 / (CD3 + CD20) ratio were both directly associated with a higher probability of shortened relapse-free survival [39]. Nevertheless, the prognostic significance of the immune cell infiltrate in the tumor microenvironment remains controversial, perhaps due to non-standardized evaluation. Therefore, it is important, and possible as described below, to identify new factors as markers of immune stromal cells associated with tumor aggressiveness. Due to the important role of the host immune system in cancer, immune checkpoint inhibitors have garnered attention during the last years, especially against cytotoxic T-lymphocyte antigen-4 (CTLA-4) and programmed cell death protein 1 (PD-1) or its ligands (PDL-1) [40].

\subsection{Endothelial Cells}

Endothelial cells (ECs) are ubiquitous within tumors and necessary for the development and functionality of vessels, especially blood vessels, essential to supply oxygen and nutrients for tumor progression. The endothelial barrier maintains vascular and tissue homeostasis but its alteration leads to vascular permeability and drives tumor-induced angiogenesis, blood flow disturbances, inflammatory cell infiltration and tumor cell extravasation. In addition, regardless of perfusion, ECs can regulate tumor growth through the secretion of paracrine factors, thereby increasing tumorigenicity, stemness and invasiveness [41-44]. All of these effects are due to the crosstalk between tumor and ECs, leading to the initiation of angiogenesis [45] and also to the development of an abnormal phenotype of ECs, which can be different depending on tumors. Thus, for example, it has been reported that ECs from highly metastatic tumors have a more proangiogenic phenotype than those from low metastatic tumors [46].

\subsection{Mesenchymal Stromal Cells}

Mesenchymal stromal cells (MSCs) are adult multipotent stromal cells, which exhibit certain common properties, ranging from the expression of surface markers (CD73, CD90, CD105), to self-renewal capability and differentiation into osteoblasts, chondrocytes and adipocytes [47,48]. MSCs preferentially reside in perivascular niches of nearly all neonatal human tissues and organs. MSCs are recruited to sites of injury where their functions are extremely diverse and depend on the tissue-specific origins and the microenvironment in which MSCs are embedded. Migration of MSCs towards the inflammation site leads to cellular interactions that occur both directly via gap junctions, membrane receptors and nanotubes and indirectly via soluble structures and factors. In physiological situations, MSCs contribute to support tissue repair, stem cell homeostasis and immunomodulation. MSCs interact with the surrounding cells by means of the secretion of soluble factors, such as cytokines or growth factors, with activities that can dramatically alter the key cellular functions of neighboring cells, such as survival, apoptosis, maturation and differentiation [49]. 
However, MSCs and their paracrine-based activity also have a relevant role in the tumor-stroma crosstalk [50,51], since MSCs themselves can be stimulated by tumor cells to develop an aberrant tumor-associated phenotype [52]. Tumor cells can recruit MSCs to the tumor site using chemotactic factors such as MMPs, growth factors and inflammatory cytokines [53]. In turn, MSCs can release paracrine signals, including cytokines, chemokines and growth factors [51], to stimulate neighboring cells with pro- and/or anti-tumorigenic activities. Thereby, MSCs, having the capability to migrate to the tumor site [54,55], display several pro-tumor functions, such as the promotion of tumor growth [56] and angiogenesis [57-59], epithelial-to-mesenchymal transition (EMT) induction [60,61], as well as alteration of the extracellular matrix $[62,63]$ to promote the migration and implantation of tumor cells to metastatic sites $[54,64]$. All of these effects, in their turn, are attained mainly by means of the secretion of pro-inflammatory cytokines [65], the suppression of immune effector cells [66-71], the expansion of immune regulatory cells $[66,70,72]$ and increasing resistance to cancer therapies $[73,74]$.

Additionally, although as previously mentioned, MSCs may be a source of CAFs, MSCs from the tumor microenvironment can also transdifferentiate into M2-type macrophages, myeloid-derived suppressor cells (MDSC) or M2-type macrophages under the influence of cytokines or chemokines [75-77].

\section{Stroma Phenotype Associated with Tumor Metastasis}

During the past 10 years, our group has investigated the relationship of different factors expressed by stromal cells associated with breast cancer metastasis. These factors include matrix metalloproteases (MMPs) and their tissue inhibitors (TIMPs), cytokines and Toll-like receptors (TLRs). Based on these data, we can propose two types of breast carcinoma stroma with significantly different influences on prognosis (Figure 1).

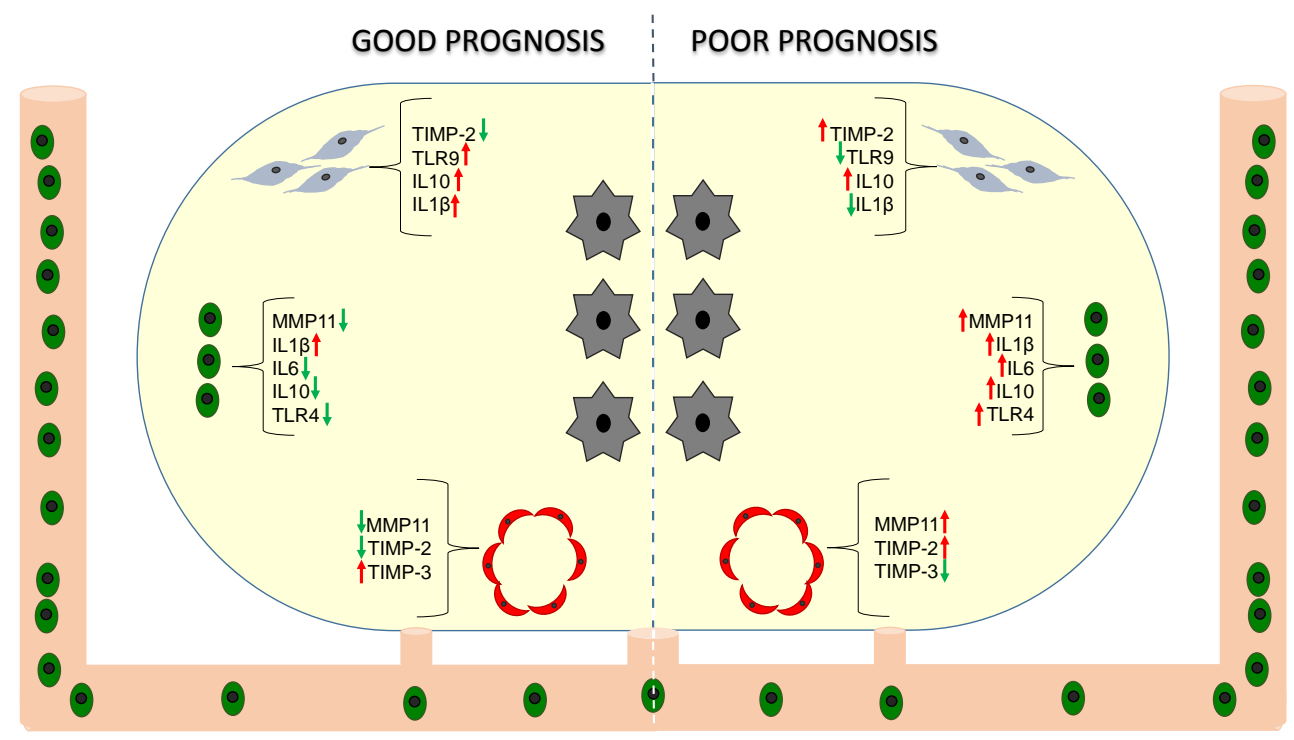

Figure 1. Stroma phenotype and prognosis. Prognostic significance of factors expressed by cancer-associated fibroblasts (CAFs, - ), mononuclear inflammatory cells (MICs, $\bullet$ ) and endothelial cells $(\mathcal{D})$ in breast cancer (tumor cells, $\hat{\sim}$ ).

\subsection{Metalloproteases and Their Inhibitors}

The human MMP family is composed by 26 members divided into six groups based on substrate specificity and homology (Table 1). MMPs play an essential role in the degradation of the stromal connective tissue and basement membrane components, which are key elements in tumor invasion and metastasis. MMPs are also able to influence in vivo tumor cell behavior due to their capacity to cleave growth factors, cell surface receptors, cell adhesion molecules and chemokines/cytokines [78,79]. 
Furthermore, by cleaving proapoptotic factors, MMPs produce a more aggressive phenotype through the generation of cells resistant to apoptosis [78]. MMPs also positively regulate cancer-related angiogenesis, through their ability to mobilize or activate proangiogenic factors (bFGF, VEGF, TGF $\beta$ and integrin $\alpha \mathrm{v} \beta 3$ ) after the degradation of basement membrane or ECM components and negatively via generation of angiogenesis inhibitors, such as angiostatin and endostatin [80]. MMP activity is specifically inhibited by TIMPs, but it is now accepted that TIMPs are multifactorial proteins also involved in the induction of tumor cell proliferation and the inhibition of apoptosis [81,82]. The role of MMPs in ECM remodeling is mainly due to their capacity to degrade the ECM, thus allowing tumor progression. In this sense, MMP-7 (matrilysin 1), with the capacity to degrade type IV collagen, fibronectin and laminin, is highly expressed in human breast tumors, inducing tumor growth and invasiveness [83]. MMP-9 (gelatinase B) is related to tumor invasion and metastasis by its special capacity to degrade type IV collagen [84] and to induce angiogenesis [78]. MMP-11 (stromelysin-3) is preferentially expressed by peritumoral stromal cells and is associated with tumor progression and poor prognosis [85-87]. MMP-13 (collagenase-3), due to its wide substrate specificity compared with other MMPs, plays a central role in the MMP activation cascade [88]. MMP-14 (membrane type 1 MMP or MT1-MMP) is involved in ECM degradation, activation of MMP-13 and MMP-2 zymogen, and in molecular carcinogenesis, tumor cell growth, invasion and angiogenesis.

Breast carcinomas containing mononuclear inflammatory cells (MICs) or CAFs with a high expression profile of MMPs and TIMPs have a higher rate of distant metastasis development compared with tumors with a low expression profile $[86,87,89,90]$, independently of luminal or basal-like phenotype of breast carcinomas [91]. However, variations in MMP/TIMP expression among the different histological subtypes of breast carcinomas (ductal, lobular, mucinous, tubular, papillary and medullary invasive carcinomas) have been found [92]. In a more recent study, we found that MMP-11 (also known as stromelysin 3) expression by MICs, and TIMP-2 expression by CAFs, either at the tumor center or at the invasive front, were the most potent independent prognostic factors for predicting the clinical outcome of patients [87]. Considering that the expression of MMP-11 may constitute a useful biological marker for pro-metastatic MICs, we investigated its relationship with the gene expression of 65 factors associated with inflammation and tumor progression in a population of breast cancer patients stratified into two groups according to MMP-11 expression by intratumoral MICs (positive or negative). Among all analyzed factors, interleukin $1 \beta$ (IL-1 $\beta$ ), IL-6, IL-17, interferon $\beta(\operatorname{IFN} \beta)$ and nuclear factor kappa B (NFkB) were expressed at high levels in tumors with MMP-11 positive MICs $[93,94]$. It has been evidenced that MMPs can either promote or repress inflammation by the direct proteolytic processing of cytokines to activate, inactivate, or antagonize their function. For example, IL-1 $\beta$ requires proteolytic processing for activation. Indeed, the IL- $1 \beta$-converting enzyme (ICE, nowadays known as caspase-1) needs the activity of MMPs, such as MMP2, -3 , and -9 , to activate the IL-1 $\beta$ precursor to the active form [95].

We also found that MMP/TIMP expression by endothelial cells (ECs) from the adjacent non-neoplastic tissue was absent or very low compared with ECs from the tumor itself. In addition, MMP-11 expression by ECs was related to distant metastasis development and shorter relapse-free survival, whereas, conversely, TIMP-3 expression was related to low occurrence of distant metastasis [96]. These results support our previous data indicating that the expression of MMP-11 by stromal cells is associated with distant metastasis development in breast cancer. Regarding TIMP-3, there are data in agreement with our own findings indicating that TIMP-3 is a naturally occurring inhibitor of angiogenesis that limits vessel density in the vascular bed of tumors and curtails tumor growth $[97,98]$. In addition, it has been reported that TIMP-3 may induce apoptosis in ECs by triggering a caspase-independent cell death pathway [99]. 
Table 1. Human matrix metalloproteases.

\begin{tabular}{|c|c|c|c|}
\hline Name of Class & MMP & Enzyme Name & Substrates \\
\hline \multirow{4}{*}{ Collagenases } & MMP-1 & Collagenase-1 & $\begin{array}{l}\text { Collagens (I, II, III, VII and X), proteoglycans, } \\
\text { entactin, ovostatin, MMP-2, MMP-9 }\end{array}$ \\
\hline & MMP-8 & $\begin{array}{l}\text { Collagenase-2/neutrophil } \\
\text { collagenase }\end{array}$ & $\begin{array}{c}\text { Collagens (I, II, III, VII, VIII and X), fibronectin, } \\
\text { proteoglycans }\end{array}$ \\
\hline & MMP-13 & Collagenase-3 & $\begin{array}{l}\text { Collagens (I, II, III, VII, VIII and X), tenascin, } \\
\text { plasminogen, aggrecan, fibronectin, } \\
\text { osteonectin, MMP-9 }\end{array}$ \\
\hline & MMP-18 & Collagenase- 4 & Type I collagen \\
\hline \multirow{2}{*}{ Gelatinases } & MMP-2 & Gelatinase-A & $\begin{array}{l}\text { Gelatin, collagen (IV, V, VII VI, IX and X), } \\
\text { elastin, fibronectin }\end{array}$ \\
\hline & MMP-9 & Gelatinase-A & $\begin{array}{l}\text { Collagens (IV, V, VII, X and XIV), gelatin, } \\
\text { entactin, elastin, fibronectin, osteonectin, } \\
\text { plasminogen, proteoglycans }\end{array}$ \\
\hline \multirow{4}{*}{ Stromelysins } & MMP-3 & Stromelysin-1 & $\begin{array}{l}\text { Collagens (IV, V and IX), gelatin, aggrecan, } \\
\text { laminin, elastin, casein, osteonectin, fibronectin, } \\
\text { ovostatin, entactin, plasminogen }\end{array}$ \\
\hline & MMP-10 & Stromelysin 2 & $\begin{array}{l}\text { Collagens (I, II, IV and V), gelatin, casein, } \\
\text { elastin, fibronectin }\end{array}$ \\
\hline & MMP-11 & Stromelysin 2 & $\begin{array}{l}\text { Collagens (IV, V, IX and X), laminin, elastin, } \\
\text { fibronectin, casein, proteoglycans }\end{array}$ \\
\hline & MMP-17 & $\begin{array}{l}\text { Homology } \\
\text { tostromelysin-2 }\end{array}$ & Pro-MMP2, fibrin/fibrinogen, gelatin \\
\hline \multirow{2}{*}{ Matrilysins } & MMP-7 & Matrilysin & $\begin{array}{l}\text { Collagens IV, gelatin, fibronectin, laminin, } \\
\text { elastin, casein, transferrin }\end{array}$ \\
\hline & MMP-26 & Matrilysin-2 & $\begin{array}{l}\text { Collagen IV, fibronectin, fibrinogen, gelatin, } \\
\text { pro-MMP9 }\end{array}$ \\
\hline \multirow{6}{*}{$\begin{array}{l}\text { MT-MMP } \\
\text { (membrane } \\
\text { type-MMP) }\end{array}$} & MMP-14 & MT1-MMP & $\begin{array}{l}\text { Collagens (I, II, III), gelatin, fibronectin, } \\
\text { laminin, vitronectin, entactin, pro-MMP2 }\end{array}$ \\
\hline & MMP-15 & MT2-MMP & $\begin{array}{l}\text { Fibronectin, gelatine, vitronectin, entactin, } \\
\text { laminin, pro-MMP-2 }\end{array}$ \\
\hline & MMP-16 & MT3-MMP & $\begin{array}{l}\text { Collagen III, gelatin, casein, fibronectin, } \\
\text { pro-MMP-2 }\end{array}$ \\
\hline & MMP-17 & MT4-MMP & Pro-MMP2, fibrinogen, gelatin \\
\hline & MMP-24 & MT5-MMP & Fibronectin, pro-MMP2, proteoglycans, gelatin \\
\hline & MMP-25 & MT6-MMP & $\begin{array}{l}\text { Pro-MMP2, pro-MMP9, collagen IV, gelatine, } \\
\text { fibronectin, Proteinase A }\end{array}$ \\
\hline \multirow{8}{*}{ Other enzymes } & MMP-12 & $\begin{array}{l}\text { Macrophage } \\
\text { metalloelastase }\end{array}$ & $\begin{array}{l}\text { Collagen IV, gelatin, elastin, casein, fibronectin, } \\
\text { vitronectin, laminin, entactin, fibrin/fibrinogen }\end{array}$ \\
\hline & MMP-19 & RASI-1 & Collagen (I, IV) gelatin, fibronectin, laminin \\
\hline & MMP-20 & Enamelysin & Amelogenin, aggrecan \\
\hline & MMP-21 & & \\
\hline & MMP-22 & & \\
\hline & MMP-23 & & Gelatin \\
\hline & MMP-28 & Epilysin & \\
\hline & MMP-29 & Unnamed & \\
\hline
\end{tabular}

\subsection{Cytokines}

Cytokines are low-molecular-weight proteins that mediate cell-to-cell communication. Immune and stromal cells, such as fibroblasts and endothelial cells, synthesize cytokines and regulate through them several processes, such as proliferation, cell survival, differentiation, immune cell activation, cell migration and death. Besides the central role of cytokines in the inflammatory process, they have also 
been recognized as powerful players in tumor progression through several pathways, including the generation of free radicals that can damage DNA, potentially causing mutations that lead to tumor initiation, stimulating cell proliferation and reducing apoptosis, stimulating EMT and angiogenesis or allowing tumor cell evasion of immune surveillance. On the other hand, cytokines can modulate an anti-tumoral response that seems conditional on the balance of pro- and anti-inflammatory cytokines, their relative concentrations, cytokine receptor expression, the activation state of surrounding cells [100] and the stage of tumor development [101].

Although previous reports have shown several positive associations between high cytokine levels and tumor aggressiveness, most of them were based on serum levels and few of them evaluated the impact on tumor recurrence [102-104]. We have reported high cytokine expression by cancer cells, supporting the recognized fact that cancer cells secrete cytokines that can act as autocrine factors contributing to their malignant phenotype. We also found different profiles of cytokine expression by stromal cells related with patient outcome [105]. Indeed, IL-1 $\beta$ expression by stromal cells (CAFs and MICs) was significantly associated with both low metastasis rate and longer relapse-free survival and overall survival, whereas IL-10 expression by stromal cells was significantly associated with higher metastasis occurrence and both shorter relapse-free survival and overall survival. In addition, the combination of IL-1 $\beta$, IL- 6 and IL-10 expression by MICs showed an important association with prognosis and improved the prognostic significance of MMP-11 status by MICs [105]. All these data seem to indicate that the non-expression of pro-inflammatory cytokines (such as IL-1 $\beta$ and IL-6), together with the expression of an anti-inflammatory cytokine (such as IL-10) could contribute to tumor immune escape. IL-10 is an important anti-inflammatory cytokine and due to its immunosuppressive effect on dendritic cells and macrophages, IL-10 can dampen antigen presentation, cell maturation and differentiation, allowing tumor cells to evade immune surveillance mechanisms [106]. These findings are in agreement with some studies suggesting that interleukins can inhibit tumor growth $[107,108]$ and that their expression can be correlated with good prognosis $[109,110]$. All of these data suggest the complexity of the tumor stroma and the importance to consider the particular cell type expressing cytokines in the context of the tumor environment.

\subsection{Toll-Like Receptors (TLRs)}

TLRs play an essential role in the activation of innate and adaptive immunity, contributing to the capacity of the immune system to combat pathogens [111]. Cancer cells activated by TLR signals may also release cytokines and chemokines that in turn may recruit immune cells and stimulate them to release further cytokines and chemokines, resulting in a cytokine profile associated with immune tolerance, tumor cell proliferation and resistance to apoptosis; but it also enhances tumor cell invasion and metastasis by regulating metalloproteases and integrins [112-114]. However, there are data supporting the importance of TLR expression by stromal cells in tumor behavior. In this sense, we have shown that TLR4 expression by MICs was associated with an increased incidence of metastasis, whereas TLR9 expression by CAFs was associated with a low metastasis-rate [115], pointing towards a protective role of TLR9 against tumor progression. Indeed, it has been shown that stimulation of TLR9 activates human plasmacytoid dendritic cells and B cells, inducing a potent innate immune response, in preclinical tumor models as well as in patients [116]. TLR9 ligands induce the expression of OX40 on $\mathrm{CD}^{+} \mathrm{T}$ cells in the tumor microenvironment. OX40, a co-stimulatory molecule belonging to the TNFR superfamily expressed on activated effector $\mathrm{T}$ cells and regulatory $\mathrm{T}$ cells, can promote effector $\mathrm{T}$ cell activation and inhibit regulatory $\mathrm{T}$ cell function, which may contribute to the eradication of spontaneous malignancy by local immunotherapy [117].

\subsection{Integrins}

Cell adhesion to the ECM is fundamental for tissue integrity and basic behavioral responses of cells under physiological conditions. Integrins are the main cell adhesion receptors for components of the ECM. The name integrin refers to the function of family members to integrate cell exteriors 
(e.g., ECM) to the cell interiors (e.g., the cytoskeleton) [118]. They are a family of 24 transmembrane heterodimers generated from a combination of $18 \alpha$ integrin (with a size of $120-170 \mathrm{kDa}$ ) and $8 \beta$ integrin (with a size of $90-100 \mathrm{kDa}$ ) chains, connected by monovalent bonds. Both $\alpha$ and $\beta$ subunits possess a large extracellular domain, a transmembrane domain and usually a small cytoplasmic tail [119]. Thus, both integrin subunits are required for interactions with the cytoskeleton and the ECM [120]. Integrins markedly differ from each other in ligand specificity and expression levels in mammalian tissues. The most common and vital for mammalian cells are fibronectin-binding integrin $\alpha 5 \beta 1$, the collagen-binding receptor $\alpha 2 \beta 1$, and integrin $\alpha \mathrm{v} \beta 3$, having a diverse ligand specificity.

The role of integrins, primary receptors for ECM and bi-directional signaling molecules, is complex because they bind to some matrix proteins and to other receptors at the same time. Integrins act as sensors of the epithelial microenvironment by affecting cells in two key ways: regulating the actin cytoskeleton of cells through binding directly with proteins (filamin, talin and vinculin) [121], or by phosphorylating the relative kinases (focal adhesion kinases (FAKs), proto-oncogene tyrosine-protein kinase (Src)-family kinases (SFKs) and integrin-linked kinase (ILK), to activate or cooperate with the other cell signaling pathways including the PI3K/Akt and MAPK/Erk pathways [122,123]. Thus, they transduce information ("outside-in") from the extracellular environment to modulate cell responses, including survival signaling, growth signaling, adhesion, spreading, migration, secretion of proteases and invasion $[124,125]$. For all of these reasons, integrins do not just bind a cell to its environment, but they have also been shown to regulate several intracellular signaling pathways, rendering their physiological role far more complex [118]. Indeed, dysregulated integrin-mediated adhesion and signaling is a precursor in the pathogenesis of many human diseases, including cancer [126].

\section{Intercellular Communication System in the Tumor Microenvironment}

The bi-directional signaling between cancer cells and stroma, mainly composed by CAFs and MICs, induces the expression of pro-tumoral factors by both tumor compartments [127-129]. These signals can be mediated by soluble factors, exosomes or via integrins.

\subsection{Soluble Factors}

Cancer cells secrete cytokines and chemokines, such as TGF- $\beta$, involved in the recruitment and activation of CAFs $[128,130]$. Furthermore, cytokines and chemokines secreted by cancer cells and CAFs, such as CCL2, contribute to the recruitment of macrophages and the induction of their transformation into tumor-associated macrophages (TAMs) [131-133]. In this sense, it has been reported that the oncogenic dysregulation of the RAS, MYC and the MAPK pathways in cancer cells contributes to the secretion of growth factors and cytokines such as VEGF, IL-6, IL-10, and IL-1 $\beta$, leading to the recruitment and the tumorigenic transformation of macrophages [134,135].

Nevertheless, after the recruitment of stromal cells in the tumor microenvironment, a complex dynamic interaction takes place, which can be evidenced by transwell-type experiments. Thus, it was demonstrated that after co-culture of CAFs and breast cancer cell lines (both MCF-7 and MDA-MB-231 cell lines), gene expression of factors related to tumor progression was significantly upregulated in both cell types (Figure 2) and invasion and angiogenic capacities of breast cancer cells were increased. Among all analyzed factors, S100A4, FGF7, PDGFB, VEGFA, TGF $\beta$, IL6, IL8, uPA, MMP2, MMP11 and TIMP1 are the more differentially expressed (Table 2) [13,136]. Additionally, the expression of some of these factors $[13,136]$ was highly increased after co-culture of breast cancer cell lines with CAFs from the primary tumor and MIC-MMP11+ cells [136], which suggests a strong pro-tumor influence of the immune original microenvironment of the CAFs. 


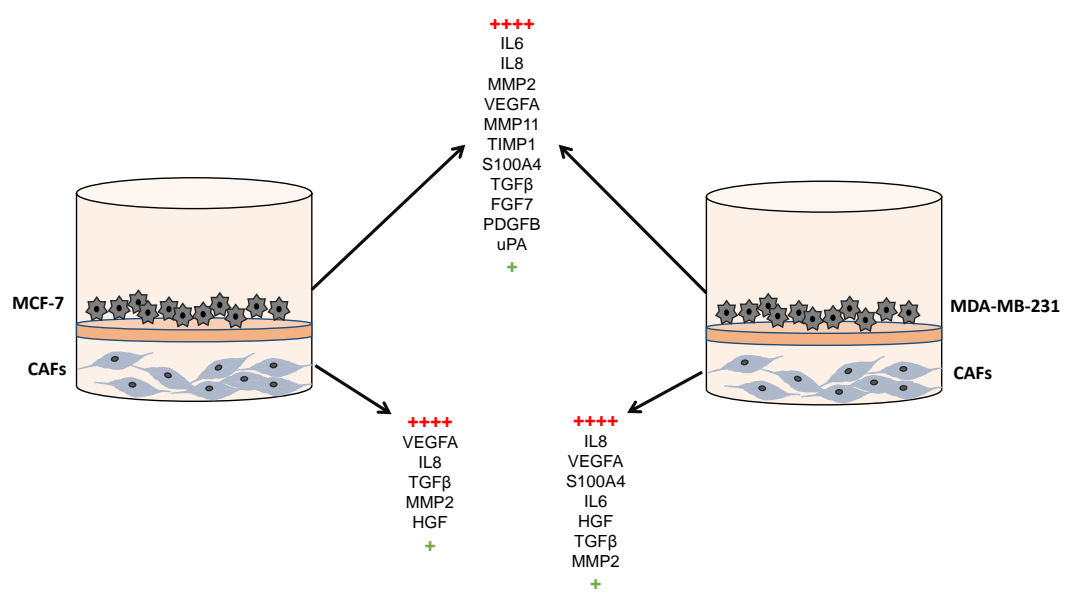

Figure 2. Gene expression of factors after co-culture between CAFs and breast cancer cell lines (MCF-7 or MDA-MB-231).

Table 2. Main role of factors implicated in the crosstalk between cancer cells and CAFs.

\begin{tabular}{ccc}
\hline Gene Symbol & Gene Name & Main Role \\
\hline S100A4 & S100 calcium binding protein A4 & Invasion \\
\hline FGF7 & Fibroblast growth factor 7 & Cell growth/Invasion \\
\hline PDGFB & Platelet-derived growth factor beta & Angiogenesis \\
\hline VEGFA & Vascular endothelial growth factor A & Angiogenesis \\
\hline TGF $\beta$ & Transforming growth factor beta & Inflammation/Invasion \\
\hline IL6 & Interleukin 6 & Inflammation \\
\hline IL8 & Interleukin 8 & Inflammation \\
\hline uPA & Urokinase-type plasminogen activator & ECM remodeling \\
\hline MMP2 & Matrix metalloproteases 2 & ECM remodeling \\
\hline MMP11 & Matrix metalloproteases 11 & ECM remodeling \\
\hline TIMP1 & Tissue inhibitor of metalloproteases 1 & ECM remodeling \\
\hline
\end{tabular}

\subsection{Exosomes}

Although soluble factors, chemokines and cytokines produced within the tumor are mainly responsible of modifications in cancer cells and stromal cells, new evidence indicates the contribution of another mode of cell communication involving extracellular vesicles (EVs). EVs, resulting in a particulate nano-communication system that may be responsible for dissemination of messages among the different cell types of the tumor, are divided into different categories depending on their size: apoptotic bodies (1000-5000 nm), microvesicles (500-1000 nm in diameter) and exosomes $(30-150 \mathrm{~nm})$ [137]. Exosomes, the smallest subset of EVs, originate in the endocytic compartment of the parent cell via a series of intraluminal invaginations taking place in the multivesicular bodies (MVBs). Consequently, their molecular content recapitulates the content of the parent cell, at least partially [138]. Exosomes are enclosed by a protein-phospholipid bilayer membrane interspersed by cell type-specific proteins, lipids and glycans. The exosome lumen is filled with various cellular proteins, nucleic acids, mRNA, miRNA and DNA, soluble factors, including cytokines and chemokines, enzymes and cofactors [139]. Exosomes produced by different cell types carry distinct molecular and genetic components, and they may be "addressed" by the parent cell to reach a specific molecular address of the recipient cell. Upon contacting a local or distantly-located recipient cell, exosomes deliver signals that culminate in cellular re-programming $[140,141]$. The mechanisms responsible for delivery and processing of the exosome cargo in recipient cells are not entirely understood, but 
may include the initial ligand-receptor type of binding on the cell surface followed by endocytosis or phagocytosis of exosomes [142].

\subsection{Tumor-Derived Exosomes (T-D-EXs)}

Tumor cells are important producers of exosomes with molecular signatures depending on the type of tumor cell, which are different from those of exosomes derived from normal cells [143,144]. Tumor-derived exosomes (T-D-EXs), ubiquitously present in the tumor environment and in body fluids of patients with cancer $[58,143]$, circulate and disseminate information to tissues and cells distant from the tumor. T-D-EXs carry messages from the parent tumor cell to other normal or malignant cells in the tumor microenvironment, including MSCs [145]. Thus, T-D-EXs can mediate autocrine, juxtacrine and paracrine signaling that the tumor cells establish and that is necessary for their survival in the tumor microenvironment [146] (Figure 3).

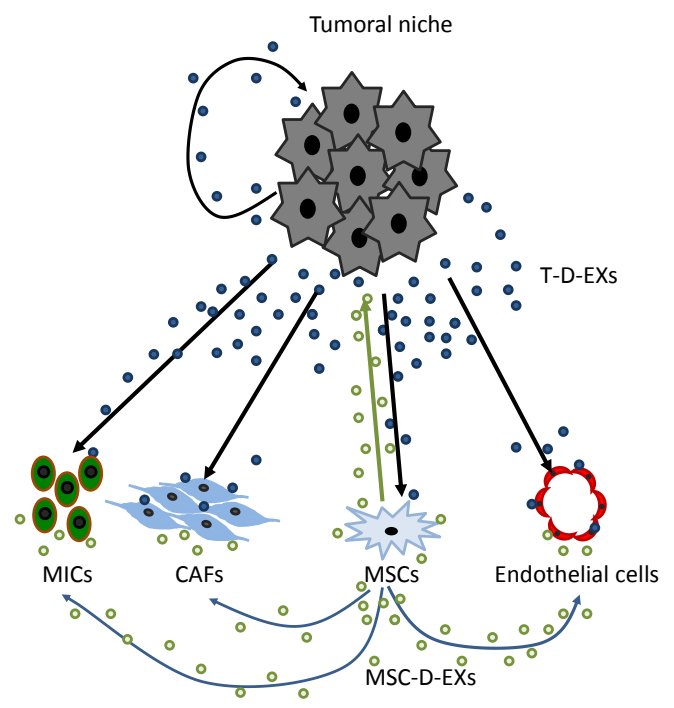

Figure 3. Paracrine communication between cancer cells and tumor microenvironment through exosomes.

\subsection{MSC-Derived Exosomes (MSC-D-EXs)}

Under normal physiological conditions, MSCs are a rich source of exosomes [64], which seem responsible for many functions generally attributed to MSCs [147], such as their contribution to the modulation of physiological functions of neighboring stromal cells [148]. It is known that MSC-derived exosomes (MSC-D-EXs), through spontaneous or organelle-mediated release, significantly contribute to the increase in extracellular ATP levels [149], which induces a favorable effect in migration and invasion of breast cancer cells [150].

Importantly, MSC-D-EXs have the capacity to interact with multiple cell types in the tumor microenvironment and to ensure they adequately support tumor growth. MSC-D-EXs carry a complex cargo of molecules and genes comprising more than 850 unique gene products and more than 150 different miRNAs $[151,152]$ and thus have the potential to elicit different cellular responses in a broad variety of cells [153]. Nevertheless, MSCs are recognized as recipients of signals emanating from the tumor, but also as efficient producers of their own and abundant exosomes [66,153]. Thus, exosomes horizontally transfer information to neighboring cells and transform the cellular milieu to one supporting tumor survival [153]. (Figure 3). It is known that T-D-EXs induce phenotypic and functional changes in MSCs which may exert profound effects on tumor growth [154], and that epigenetic modifications mediated by genetic elements introduced by exosomes to recipient MSCs appear to be involved [155]. At present, the cellular, molecular and genetic mechanisms responsible for re-programming of MSCs by T-D-EXs are under intense scrutiny. The initial contact may be due to T-D-EXs carrying numerous cell adhesion molecules (CAMs) whereby they can readily fuse with 
adhesion receptors on MSCs allowing for the protein/gene transfer to the MSCs cytosol. It remains unclear whether the protein transfer alone is sufficient for the re-programming of MSCs by T-D-EXs or whether the transfer of transcription factors and nucleic acids is mandatory. These changes in MSCs include the overexpression of genes involved in cell migration (CXCR4 and CXCR7), in the matrix remodeling (collagen type IV alpha 3 chain) and in angiogenesis or tumor growth (IL-8, OPN and myeloperoxidase) [156]. T-D-EXs from prostate cancer, breast cancer or chronic lymphocytic leukaemia can promote MSC migration to the tumor site [55] and induce MSC differentiation into myelofibroblasts overexpressing alpha smooth muscle actin ( $\alpha \mathrm{SMA})[65]$.

\subsection{Integrins and Cancer}

Alterations of integrin expression and function, linked to many types of cancer [157,158], lead to modifications which are the basis of tumor progression, such as dedifferentiation, proliferation, apoptosis or disorganization of the ECM and promotion of metastasis [122,157,159-163]. Therefore, integrins have been implicated in different steps of cancer progression, such as cancer initiation and proliferation, local invasion and intravasation, survival of circulating tumor cells (CTCs), extravasation and metastatic colonization [163].

Regarding breast cancer, experimental data implicate integrins such as $\beta 1$ integrins, and more specifically $\alpha 3 \beta 1$ integrin, in mammary tumorigenesis [164,165]. Likewise, aberrant expression of $\beta 1$ integrin in human breast carcinoma has been linked to cell adhesion, angiogenesis, tumor progression and metastasis [166-168]. In agreement with these findings, there are clinical data demonstrating that integrin overexpression, such as that of $\beta 1$ integrin [167-169] or integrin $\alpha 6$ [170], are associated with a poor prognosis and reduced survival, or with radiation resistance [171]. Nevertheless, the functions of individual integrins in invasion and metastasis processes are controversial. Thus, for example, it has been reported that inhibition of $\beta 1$ integrin significantly reduces the formation of metastatic foci of several cancer types, including breast cancer [172]; or that $\alpha 2 \beta 1$ suppressed metastatic dissemination in a mouse model of spontaneous breast cancer [173]. In addition, some studies have reported that decreased $\beta 1$ integrin protein expression is associated with more aggressive breast cancer types $[174,175]$, whereas other studies could not verify a significant correlation between integrin subunit $\beta 1$ (ITGB1) protein expression and survival of patients with breast carcinoma [176,177]. These contradictory data may be due to the diversity of the integrin family and the variety of signal pathways that a particular receptor can induce in different cells, as well as to differences between the different tumor histotypes in signaling pathways initiated by integrins. Therefore, it may be of key importance to consider the role of integrins in the context of tumor stroma heterogeneity, representing an exciting new way to explore the complexity of biological systems.

\subsection{Possible Role of Integrins to Better Characterize the Tumor Stroma Phenotype in Breast Cancer}

Integrins are widely expressed by many types of cells, including tumor cells, endothelial cells (ECs), pericytes, fibroblasts and immune cells. Therefore, integrins play key roles in other cancer-relevant processes, such as white blood cell trafficking and activation, chronic inflammation and angiogenesis, which are strongly related to cancer progression [163]. The contribution of CAFs to cancer progression and tumor invasion is mediated via several integrin-linked mechanisms [178,179]. CAFs align fibronectin fibres within the tumor ECM and, through application of traction forces mediated by $\alpha 5 \beta 1$ integrin, promote directional cancer cell migration [180]. Additionally, CAFs are able to induce tamoxifen resistance by secreting fibronectin, which stimulates its ligand integrin $\beta 1$ to activate signaling pathways, such as the PI3K/AKT pathway [181] and long-term exposure to CAFs makes breast cancer cells addictive to integrin $\beta 1$ [182].

Although integrin-mediated cell-to-cell and cell-to-matrix interactions during the T-cell lifespan still represent an open field of research, there are data indicating that integrins in lymphocytes or macrophages also play a key role to promote tumor progression. Thus, several mechanisms implicate integrins in the infiltration of lymphocytes and macrophages into tumors. This may be 
by a dynamic integration of integrins with several extracellular factors, such as the ECM protein periostin [183], osteopontin-rich matrix [184], VCAM-1 [185,186] or fibronectin [185]. In addition, it has been reported that $\alpha \mathrm{L} \beta 2$ affinity down-modulation is crucial in promoting the intravascular crawling and diapedesis of T-cells during homing to peripheral lymph nodes [187]. Integrins also generate a signal that interacts with chemokines and antigens to modulate T-cell motility, proliferation and differentiation [188]. Endothelial cells use integrins to interact with their underlying basement membrane, which combined with tyrosine kinase-induced signaling are important regulators of vessel integrity and tumor progression, since integrin expression both on cancer cells and on endothelial cells is implicated in extravasation [189].

Interestingly, integrins also regulate proteins, such as MMPs and fibronectin, which play key roles in the dynamics of the proteolytic activity from tumor stroma and the metastasic cascade. Integrins contribute to the latter by upregulating the expression of MMP genes and facilitating protease activation and function at the ECM interface [190]. In addition, integrins, such as $\alpha \mathrm{V} \beta 3$ cooperate with MMPs, such as MMP-2 [191], MMP-9 [192] and MMP-14 [193], in regulating migration of metastatic breast cancer cells toward specific substrates in an activation-dependent pathway. Indeed, it has been demonstrated that integrins control MMP-2 and MMP-9 expression regulating angiogenesis in breast tumor cells and endothelial cells [194]. In fact, the inhibition of MMP-9 and $\alpha_{V} \beta_{5}$-integrin interaction results in a reduced angiogenesis and tumor invasion [195].

The arginine (R)-glycine (G)-aspartic acid (D) (RGD) sequence is included in the adhesion molecule fibronectin, which is the ligand for several types of integrins, such as $\alpha 5 \beta 1, \alpha \mathrm{v} \beta 3$ and $\alpha \mathrm{v} \beta 5$ [124]. Integrins, after binding to fibronectin, activate focal adhesion kinase (FAK), which further activates multiple signaling proteins, promoting directional cancer cell migration through the activation of cytoskeletal contractility $[178,180]$. It is also worth mentioning that integrin-fibronectin interactions are also implicated in induced exit of cancer cells from dormancy [196,197], as well as in radiotherapy resistance $[198,199]$. As was mentioned above, there are new data which implicate exosomes in playing a vital role in the development of organ-specific metastasis [200], integrins being the most highly expressed receptors on their surface. These associations might contribute to support the "seed and soil" hypothesis proposed by Paget more than 100 years ago [201]. This is because integrins facilitate the binding and fusion of extracellular vesicles to the plasma membrane of their cell targets [202]. Thus, exosomal integrins can contribute to initiate organ colonization of specific tissues by preparing favorable pre-metastatic niches to metastatic niche formation [200,203-205]. With regard to this, it has been shown that integrins $\alpha \mathrm{v} \beta 5, \alpha 6 \beta 4$ and $\alpha 6 \beta 1$ on tumor-derived exosomes could drive tumor cells to metastasize to specific organs like lung, liver or brain [203].

\subsection{Tumor Stroma and Therapeutic Opportunities}

A consolidated example of targeting stroma in breast cancer are the different strategies available to target angiogenic cells in clinical trials of advanced breast cancer [206]. In addition, cancer therapies should aim for a progressive disruption of the dynamics of interactions between cancer cells and the tumor microenvironment by targeting metabolic dysregulation and inflammation to partially restore tissue homeostasis and turn on the immune cancer kill switch. The translation of this therapeutic approach to established treatments would, however, require more understanding of the adaptive complexity of cancer resulting from the interactions of cancer cells with the tumor microenvironment and the immune system.

Studies investigating the role of CAFs have reported that the therapeutic targeting of cancer cells alone is not enough for the treatment of cancer [207]. CAFs are essential components of the tumor microenvironment and therefore, represent a molecular target for the treatment of cancer [208]. In addition, compared with cancer cells, CAFs are genetically more stable with a reduced probability of developing drug-resistance, thus representing a potential therapeutic target with a lower probability of long-term chemoresistance development $[209,210]$. Different strategies implicating CAFs could be developed, such as targeting the ability of CAFs to exert mechanical forces on the basal membrane [6], or 
induce the reduction of lactate and steer the tumor microenvironment to a state of reduced inflammation so as to enable an effective intervention of the immune system. This is because the probability of dysregulation of the RTK, PI3K and MAPK signaling pathways is significantly high for most types of cancer. Driven by growth factors from the stroma, these pathways may, with high probability, be the first drivers of an upregulated glycolysis in cancer cells. The consequent increase of lactate secretion into the tumor microenvironment will thereafter lead to its acidification and the activation of TGF- $\beta$ [211], leading to the recruitment and transformation of CAFs. On the other hand, several new agents blocking CAF pro-tumor activity have undergone pre-clinical and clinical evaluation [12,212,213]. Several clinical trials have also been implemented in order to evaluate inhibitors of cytokine receptors or neutralizing antibodies that prevent the sustained exposure to these inflammatory mediators that promote tumor progression $[214,215]$. Among the most implemented clinical trials for breast cancer in the metastatic setting are those involving drugs that target immune-cell-intrinsic checkpoints. Blockade of one of these checkpoints, cytotoxic T-lymphocyte-associated antigen-4 (CTLA-4) or the programmed cell death 1 (PD-1) receptor, may provide proof of concept for the activity of an immune-modulation approach in the treatment of breast cancer [216]. As it was previously reported, MSC biology is of great interest for cancer progression and could lead to new therapeutic strategies. Thus, for example, it has recently been reported that the trophic effect of MSCs on breast cancer cell growth is exerted via ionotropic purinergic signaling, suggesting the inhibition of the purinergic signaling system as a potential target for therapeutic intervention [217]. Nevertheless, contradictory results have been described regarding induced pro- or anti-tumor effects, both in vitro and in vivo [218]. These discrepancies in MSC functionality may also be due to their heterogeneity and to the fact that no specific surface markers currently exist to isolate a more homogeneous population. Some data point towards the importance of the source of MSCs with regard to their tumorigenic properties. Thus, for example, bone marrow-derived MSCs (BM-MSC-CM) have both anti-tumor effects on non-small cell lung cancer cells [219] and stimulatory effects on myeloma cells [220], whereas adipose tissue-derived MSCs conditioned medium (ADSC-CM) has no effect on human glioblastoma cancer stem cell subpopulations [221]. Therefore, a possible alternative would be to find an MSC-tissue source providing a unique anti-tumor activity. Regarding this aspect, we recently identified the human cervix as a new source of MSCs, named human uterine cervical stem cells (hUCESCs), which are obtained from the transformation zone of the uterine cervix of healthy women by means of Pap cervical smears [222]. Our results show specific anti-tumor effects of conditioned medium from hUCESCs (hUCESCs-CM) on proliferation, apoptosis, tumor-cell invasiveness and aggressive behavior of breast cancer cells in vitro (MDA-MB-231 breast cancer cell lines and primary tumors) and reduced tumor growth in vivo in a mouse xenograft tumor model, which differ from those reported for other types of MSC-CM [223-225]. We also explored the effect of hUCESCs-CM treatment on CAFs and on monocyte to macrophage differentiation [222]. In this sense, we established that co-culture with hUCESCs as well as treatment with hUCESCs-CM significantly reduced CAF cell proliferation and invasion, and increased early apoptosis. We also observed that treatment with hUCESCs-CM significantly inhibited and reversed macrophage differentiation. These are interesting findings, because the use of secretome and conditioned medium from MSCs is considered a new therapeutic strategy [226].

The secretome, emerging as a novel type of biological regulation involving the communication between cells, is defined as the set of factors/molecules secreted to the extracellular space. These factors include, among others, soluble proteins, free nucleic acids, lipids and extracellular vesicles including exosomes. The use of cell-free therapies such as MSC-sourced secretome in regenerative medicine provides key advantages over stem-cell based applications [226]: its application resolves several safety considerations potentially associated with the transplantation of living and proliferating cell populations (immune compatibility, tumorigenicity, emboli formation and the transmission of infections); it may be evaluated for safety, dosage and potency in a manner analogous to conventional pharmaceutical agents; its storage can be performed without application of potentially toxic cryopreservative agents for a long period without loss of product potency; it is more economical and more practical for 
clinical application since it avoids invasive cell collection procedures; its mass-production is possible through tailor-made cell lines under controlled laboratory conditions; etc. Our study revealed that hUCESCs-CM had a higher concentration than control media or ASCs-CM of factors such as LIGHT (or TNFSF14), Fms-related tyrosine kinase 3 ligand (FLT-3 ligand), interferon-gamma-inducible protein-10 (IP-10) and latency-associated protein [222]. These factors have been associated with induction of apoptosis, inhibition of cell growth, reduced cell invasion and tumor inhibition. It is also noteworthy that, compared to ASCs-CM, hUCESCs-CM contains lower levels of factors known to participate in cancer progression, such as epidermal growth factor receptor (EGFR), fibroblast growth factor (FGF) 4 and 9, Intercellular adhesion molecule 3 (ICAM3), IL6, IL6R, monocyte chemotactic protein-3 MCP3 (also named CCL7), macrophage migration inhibitory factor (MIF), sgp130 and vascular endothelial growth factor D (VEGFD) [222]. This, again, indicates that the properties of MSCs and their secretomes vary depending on their source. All of these findings related to the anatomical source of hUCESCs [227], suggest that a complex paracrine signaling network is implicated in the anti-tumor potential of this MSC type. In addition, recent in vitro data of our group demonstrate that exosomes derived from hUCESCs show an anti-tumor effect (unpublished data), which is interesting because of the potential for future therapeutic interventions for cancer control via MSCs-derived exosomes.

On the other hand, integrins may be interesting therapeutic targets because they are expressed by stromal cells from primary tumors and from metastatic niches (CAFs, immune-cells or endothelial cells) and on tumor-derived exosomes [163]. In fact, previous studies have demonstrated that blocking integrins with synthetic peptides, antibodies, or disintegrins, interferes with tumor cell invasion and metastasis in vitro and in vivo [228,229]. Nevertheless, there is still need for reliable predictive biomarkers for patient stratification, as well as the correspondent detection tools, such as antibodies which reliably function in immunohistochemistry performed on formalin-fixed, paraffin-embedded material [229].

Their development would be a major step forward in the integrin field to translate preclinical efficacy into a beneficial treatment for patients.

\section{Conclusions and Future Perspectives}

Studies on the cellular components of breast cancer stroma have identified new biological markers, such as MMPs, TIMPs, cytokines or TLRs leading to the definition of main phenotypes with different prognoses. These and other factors, such as exosomes derived from cancer cells, MSCs and integrins, could allow us in the near future to identify pathways of intercellular communication leading to new therapeutic strategies in breast cancer.

Studies investigating the role of tumor stromal cells have reported that the therapeutic targeting of cancer cells alone is not enough for the treatment of cancer. There is evidence indicating that the tumor microenvironment is a fertile ground for the development of novel therapies with the potential to augment existing treatment and prevention options. In addition, compared to cancer cells, stromal cells are relatively stable from the genetic point of view, with a reduced probability of developing drug-resistance, thus representing a potential therapeutic target with lower chances for the development of long-term chemoresistance. Several clinical trials have been implemented in order to evaluate blocking CAFs or inhibitors of cytokine receptors or neutralizing antibodies that prevent the sustained exposure to inflammatory mediators that promote tumor progression. MSC biology is also of great interest in cancer progression and could lead to new therapeutic strategies. A possible alternative would be to find an MSC-tissue source providing a unique anti-tumor activity. With regard to it, hUCESCs have shown a wide anti-tumor effect against aggressive breast cancer in both in vitro and in vivo studies, against CAFs and on monocyte to macrophage differentiation in breast cancer. $\mathrm{CM}$ or secretome from hUCESCs emerges as an interesting and potential anticancer cell-free therapy in regenerative medicine, providing key advantages over stem-cell based applications, resolving several safety considerations potentially associated with the transplantation of living and proliferative cell populations, and carrying several technical advantages for its application. Finally, considering that 
integrins are key players in metastasis and are expressed by stromal cells from primary tumors and from metastatic niches and on tumor-derived exosomes, targeting integrins may be an important innovative therapy to explore when considering future therapeutic options based on tumor stroma activity blockage.

Author Contributions: N.E., L.O.G., M.F. and S.C. analyzed the bibliography and prepared the tables and figures. N.E., J.S. and F.J.V. designed the project and wrote the manuscript. All authors reviewed the manuscript.

Funding: This study was supported by Instituto de Salud Carlos III (PI17/02236) to F.J.V., and by Fundación para la Investigación en Células Madre Uterinas (FICEMU).

Conflicts of Interest: The authors declare the following competing interests: F.J.V. and N.E. are co-inventors of a patent ("Human uterine cervical stem cell population and uses thereof") owned by GiStem Research, of which N.E., L.O.G., S.C., J.S. and F.J.V. are shareholders. The founding sponsors had no role in the design of this review, in the collection, analyses, or interpretation of data, in the writing of the manuscript, or in the decision to publish the results.

\section{References}

1. Balkwill, F.R.; Capasso, M.; Hagemann, T. The tumor microenvironment at a glance. J. Cell Sci. 2012, 125, 5591-5596. [CrossRef]

2. Anderberg, C.; Pietras, K. On the origin of cancer-associated fibroblasts. Cell Cycle 2009, 8, 1461-1462. [CrossRef]

3. Zhu, C.Q.; Popova, S.N.; Brown, E.R.; Barsyte-Lovejoy, D.; Navab, R.; Shih, W.; Li, M.; Lu, M.; Jurisica, I.; Penn, L.Z.; et al. Integrin alpha 11 regulates IGF2 expression in fibroblasts to enhance tumorigenicity of human non-small-cell lung cancer cells. Proc. Natl. Acad. Sci. USA 2007, 104, 11754-11759. [CrossRef]

4. Nakagawa, H.; Liyanarachchi, S.; Davuluri, R.V.; Auer, H.; Martin, E.W., Jr.; de la Chapelle, A.; Frankel, W.L. Role of cancer-associated stromal fibroblasts in metastatic colon cancer to the liver and their expression profiles. Oncogene 2004, 23, 7366-7377. [CrossRef] [PubMed]

5. Walter, K.; Omura, N.; Hong, S.M.; Griffith, M.; Vincent, A.; Borges, M.; Goggins, M. Overexpression of smoothened activates the sonic hedgehog signaling pathway in pancreatic cancer-associated fibroblasts. Clin. Cancer Res. 2010, 16, 1781-1789. [CrossRef] [PubMed]

6. Glentis, A.; Oertle, P.; Mariani, P.; Chikina, A.; El Marjou, F.; Attieh, Y.; Zaccarini, F.; Lae, M.; Loew, D.; Dingli, F.; et al. Cancer-associated fibroblasts induce metalloprotease-independent cancer cell invasion of the basement membrane. Nat. Commun. 2017, 8, 924. [CrossRef]

7. Koontongkaew, S. The tumor microenvironment contribution to development, growth, invasion and metastasis of head and neck squamous cell carcinomas. J. Cancer 2013, 4, 66-83. [CrossRef]

8. Madar, S.; Goldstein, I.; Rotter, V. 'Cancer associated fibroblasts'-More than meets the eye. Trends Mol. Med. 2013, 19, 447-453. [CrossRef]

9. Erez, N.; Truitt, M.; Olson, P.; Arron, S.T.; Hanahan, D. Cancer-Associated Fibroblasts Are Activated in Incipient Neoplasia to Orchestrate Tumor-Promoting Inflammation in an NF-kappaB-Dependent Manner. Cancer Cell 2010, 17, 135-147. [CrossRef] [PubMed]

10. Kalluri, R.; Zeisberg, M. Fibroblasts in cancer. Nat. Rev. Cancer 2006, 6, 392-401. [CrossRef] [PubMed]

11. Allen, M.; Louise Jones, J. Jekyll and Hyde: The role of the microenvironment on the progression of cancer. J. Pathol. 2011, 223, 162-176. [CrossRef]

12. Mao, Y.; Keller, E.T.; Garfield, D.H.; Shen, K.; Wang, J. Stromal cells in tumor microenvironment and breast cancer. Cancer Metastasis Rev. 2013, 32, 303-315. [CrossRef] [PubMed]

13. Gonzalez, L.; Eiro, N.; Fernandez-Garcia, B.; Gonzalez, L.O.; Dominguez, F.; Vizoso, F.J. Gene expression profile of normal and cancer-associated fibroblasts according to intratumoral inflammatory cells phenotype from breast cancer tissue. Mol. Carcinog. 2016, 55, 1489-1502. [CrossRef] [PubMed]

14. Kogan-Sakin, I.; Cohen, M.; Paland, N.; Madar, S.; Solomon, H.; Molchadsky, A.; Brosh, R.; Buganim, Y.; Goldfinger, N.; Klocker, H.; et al. Prostate stromal cells produce CXCL-1, CXCL-2, CXCL-3 and IL-8 in response to epithelia-secreted IL-1. Carcinogenesis 2009, 30, 698-705. [CrossRef] [PubMed]

15. Protti, M.P.; De Monte, L. Cross-talk within the tumor microenvironment mediates Th2-type inflammation in pancreatic cancer. Oncoimmunology 2012, 1, 89-91. [CrossRef] 
16. Straussman, R.; Morikawa, T.; Shee, K.; Barzily-Rokni, M.; Qian, Z.R.; Du, J.; Davis, A.; Mongare, M.M.; Gould, J.; Frederick, D.T.; et al. Tumour micro-environment elicits innate resistance to RAF inhibitors through HGF secretion. Nature 2012, 487, 500-504. [CrossRef]

17. Sun, X.; Mao, Y.; Wang, J.; Zu, L.; Hao, M.; Cheng, G.; Qu, Q.; Cui, D.; Keller, E.T.; Chen, X.; et al. IL-6 secreted by cancer-associated fibroblasts induces tamoxifen resistance in luminal breast cancer. Oncogene 2014. [CrossRef]

18. De Visser, K.E.; Eichten, A.; Coussens, L.M. Paradoxical roles of the immune system during cancer development. Nat. Rev. Cancer 2006, 6, 24-37. [CrossRef] [PubMed]

19. Lin, E.Y.; Pollard, J.W. Role of infiltrated leucocytes in tumour growth and spread. Br. J. Cancer 2004, 90, 2053-2058. [CrossRef]

20. Coussens, L.M.; Werb, Z. Inflammation and cancer. Nature 2002, 420, 860-867. [CrossRef]

21. Daniel, D.; Chiu, C.; Giraudo, E.; Inoue, M.; Mizzen, L.A.; Chu, N.R.; Hanahan, D. CD4+ T cell-mediated antigen-specific immunotherapy in a mouse model of cervical cancer. Cancer Res. 2005, 65, 2018-2025. [CrossRef]

22. Sica, A.; Bronte, V. Altered macrophage differentiation and immune dysfunction in tumor development. J. Clin. Investig. 2007, 117, 1155-1166. [CrossRef] [PubMed]

23. Balkwill, F. Cancer and the chemokine network. Nat. Rev. Cancer 2004, 4, 540-550. [CrossRef] [PubMed]

24. Le Bitoux, M.A.; Stamenkovic, I. Tumor-host interactions: The role of inflammation. Histochem. Cell Biol. 2008, 130, 1079-1090. [CrossRef] [PubMed]

25. Bingle, L.; Brown, N.J.; Lewis, C.E. The role of tumour-associated macrophages in tumour progression: Implications for new anticancer therapies. J. Pathol. 2002, 196, 254-265. [CrossRef]

26. Lewis, C.E.; Pollard, J.W. Distinct role of macrophages in different tumor microenvironments. Cancer Res. 2006, 66, 605-612. [CrossRef]

27. Alexe, G.; Dalgin, G.S.; Scanfeld, D.; Tamayo, P.; Mesirov, J.P.; DeLisi, C.; Harris, L.; Barnard, N.; Martel, M.; Levine, A.J.; et al. High expression of lymphocyte-associated genes in node-negative HER2+ breast cancers correlates with lower recurrence rates. Cancer Res. 2007, 67, 10669-10676. [CrossRef] [PubMed]

28. Arnould, L.; Gelly, M.; Penault-Llorca, F.; Benoit, L.; Bonnetain, F.; Migeon, C.; Cabaret, V.; Fermeaux, V.; Bertheau, P.; Garnier, J.; et al. Trastuzumab-based treatment of HER2-positive breast cancer: An antibody-dependent cellular cytotoxicity mechanism? Br. J. Cancer 2006, 94, 259-267. [CrossRef]

29. Bates, G.J.; Fox, S.B.; Han, C.; Leek, R.D.; Garcia, J.F.; Harris, A.L.; Banham, A.H. Quantification of regulatory T cells enables the identification of high-risk breast cancer patients and those at risk of late relapse. J. Clin. Oncol. 2006, 24, 5373-5380. [CrossRef]

30. Desmedt, C.; Haibe-Kains, B.; Wirapati, P.; Buyse, M.; Larsimont, D.; Bontempi, G.; Delorenzi, M.; Piccart, M.; Sotiriou, C. Biological processes associated with breast cancer clinical outcome depend on the molecular subtypes. Clin. Cancer Res. 2008, 14, 5158-5165. [CrossRef]

31. Rody, A.; Holtrich, U.; Pusztai, L.; Liedtke, C.; Gaetje, R.; Ruckhaeberle, E.; Solbach, C.; Hanker, L.; Ahr, A.; Metzler, D.; et al. T-cell metagene predicts a favorable prognosis in estrogen receptor-negative and HER2-positive breast cancers. Breast Cancer Res. 2009, 11, R15. [CrossRef]

32. Denkert, C.; Loibl, S.; Noske, A.; Roller, M.; Muller, B.M.; Komor, M.; Budczies, J.; Darb-Esfahani, S.; Kronenwett, R.; Hanusch, C.; et al. Tumor-associated lymphocytes as an independent predictor of response to neoadjuvant chemotherapy in breast cancer. J. Clin. Oncol. 2010, 28, 105-113. [CrossRef] [PubMed]

33. Lofdahl, B.; Ahlin, C.; Holmqvist, M.; Holmberg, L.; Zhou, W.; Fjallskog, M.L.; Amini, R.M. Inflammatory cells in node-negative breast cancer. Acta Oncol. 2012, 51, 680-686. [CrossRef] [PubMed]

34. Mahmoud, S.M.; Paish, E.C.; Powe, D.G.; Macmillan, R.D.; Lee, A.H.; Ellis, I.O.; Green, A.R. An evaluation of the clinical significance of FOXP3+ infiltrating cells in human breast cancer. Breast Cancer Res. Treat. 2011, 127, 99-108. [CrossRef] [PubMed]

35. Mahmoud, S.M.; Lee, A.H.; Paish, E.C.; Macmillan, R.D.; Ellis, I.O.; Green, A.R. The prognostic significance of B lymphocytes in invasive carcinoma of the breast. Breast Cancer Res. Treat. 2012, 132, 545-553. [CrossRef] [PubMed]

36. Takenaka, M.; Seki, N.; Toh, U.; Hattori, S.; Kawahara, A.; Yamaguchi, T.; Koura, K.; Takahashi, R.; Otsuka, H.; Takahashi, H.; et al. FOXP3 expression in tumor cells and tumor-infiltrating lymphocytes is associated with breast cancer prognosis. Mol. Clin. Oncol. 2013, 1, 625-632. [CrossRef] [PubMed] 
37. Ibrahim, E.M.; Al-Foheidi, M.E.; Al-Mansour, M.M.; Kazkaz, G.A. The prognostic value of tumor-infiltrating lymphocytes in triple-negative breast cancer: A meta-analysis. Breast Cancer Res. Treat. 2014, 148, 467-476. [CrossRef]

38. Yeong, J.; Thike, A.A.; Lim, J.C.; Lee, B.; Li, H.; Wong, S.C.; Hue, S.S.; Tan, P.H.; Iqbal, J. Higher densities of Foxp3(+) regulatory $\mathrm{T}$ cells are associated with better prognosis in triple-negative breast cancer. Breast Cancer Res. Treat. 2017, 163, 21-35. [CrossRef]

39. Eiro, N.; Pidal, I.; Fernandez-Garcia, B.; Junquera, S.; Lamelas, M.L.; del Casar, J.M.; Gonzalez, L.O.; Lopez-Muniz, A.; Vizoso, F.J. Impact of CD68/(CD3+CD20) ratio at the invasive front of primary tumors on distant metastasis development in breast cancer. PLoS ONE 2012, 7, e52796. [CrossRef] [PubMed]

40. Webb, E.S.; Liu, P.; Baleeiro, R.; Lemoine, N.R.; Yuan, M.; Wang, Y.H. Immune checkpoint inhibitors in cancer therapy. J. Biomed. Res. 2018, 32, 317-326. [CrossRef] [PubMed]

41. Butler, J.M.; Kobayashi, H.; Rafii, S. Instructive role of the vascular niche in promoting tumour growth and tissue repair by angiocrine factors. Nat. Rev. Cancer 2010, 10, 138-146. [CrossRef]

42. Butler, J.M.; Rafii, S. Generation of a vascular niche for studying stem cell homeostasis. Methods Mol. Biol. 2012, 904, 221-233. [CrossRef]

43. Ghajar, C.M.; Peinado, H.; Mori, H.; Matei, I.R.; Evason, K.J.; Brazier, H.; Almeida, D.; Koller, A.; Hajjar, K.A.; Stainier, D.Y.; et al. The perivascular niche regulates breast tumour dormancy. Nat. Cell Biol. 2013, 15, 807-817. [CrossRef]

44. Ghiabi, P.; Jiang, J.; Pasquier, J.; Maleki, M.; Abu-Kaoud, N.; Rafii, S.; Rafii, A. Endothelial cells provide a notch-dependent pro-tumoral niche for enhancing breast cancer survival, stemness and pro-metastatic properties. PLoS ONE 2014, 9, e112424. [CrossRef]

45. Folkman, J.; Watson, K.; Ingber, D.; Hanahan, D. Induction of angiogenesis during the transition from hyperplasia to neoplasia. Nature 1989, 339, 58-61. [CrossRef]

46. Hida, K.; Ohga, N.; Akiyama, K.; Maishi, N.; Hida, Y. Heterogeneity of tumor endothelial cells. Cancer Sci. 2013, 104, 1391-1395. [CrossRef]

47. Lazennec, G.; Jorgensen, C. Concise review: Adult multipotent stromal cells and cancer: Risk or benefit? Stem Cells 2008, 26, 1387-1394. [CrossRef]

48. Dominici, M.; Le Blanc, K.; Mueller, I.; Slaper-Cortenbach, I.; Marini, F.; Krause, D.; Deans, R.; Keating, A.; Prockop, D.; Horwitz, E. Minimal criteria for defining multipotent mesenchymal stromal cells. The International Society for Cellular Therapy position statement. Cytotherapy 2006, 8, 315-317. [CrossRef]

49. Timmers, L.; Lim, S.K.; Arslan, F.; Armstrong, J.S.; Hoefer, I.E.; Doevendans, P.A.; Piek, J.J.; El Oakley, R.M.; Choo, A.; Lee, C.N.; et al. Reduction of myocardial infarct size by human mesenchymal stem cell conditioned medium. Stem Cell Res. 2007, 1, 129-137. [CrossRef]

50. Ridge, S.M.; Sullivan, F.J.; Glynn, S.A. Mesenchymal stem cells: Key players in cancer progression. Mol. Cancer 2017, 16, 31. [CrossRef]

51. Lazennec, G.; Lam, P.Y. Recent discoveries concerning the tumor-Mesenchymal stem cell interactions. Biochim. Biophys. Acta 2016, 1866, 290-299. [CrossRef]

52. Hass, R.; Otte, A. Mesenchymal stem cells as all-round supporters in a normal and neoplastic microenvironment. Cell Commun. Signal 2012, 10, 26. [CrossRef]

53. El-Haibi, C.P.; Karnoub, A.E. Mesenchymal stem cells in the pathogenesis and therapy of breast cancer. J. Mammary Gland Biol. Neoplasia 2010, 15, 399-409. [CrossRef] [PubMed]

54. Anthony, B.A.; Link, D.C. Regulation of hematopoietic stem cells by bone marrow stromal cells. Trends Immunol. 2014, 35, 32-37. [CrossRef] [PubMed]

55. Sanchez, C.A.; Andahur, E.I.; Valenzuela, R.; Castellon, E.A.; Fulla, J.A.; Ramos, C.G.; Trivino, J.C. Exosomes from bulk and stem cells from human prostate cancer have a differential microRNA content that contributes cooperatively over local and pre-metastatic niche. Oncotarget 2016, 7, 3993-4008. [CrossRef] [PubMed]

56. Zhu, W.; Huang, L.; Li, Y.; Zhang, X.; Gu, J.; Yan, Y.; Xu, X.; Wang, M.; Qian, H.; Xu, W. Exosomes derived from human bone marrow mesenchymal stem cells promote tumor growth in vivo. Cancer Lett. 2012, 315, $28-37$. [CrossRef] [PubMed]

57. Melzer, C.; Yang, Y.; Hass, R. Interaction of MSC with tumor cells. Cell Commun. Signal 2016, 14, 20. [CrossRef]

58. Szczepanski, M.J.; Szajnik, M.; Welsh, A.; Whiteside, T.L.; Boyiadzis, M. Blast-derived microvesicles in sera from patients with acute myeloid leukemia suppress natural killer cell function via membrane-associated transforming growth factor-beta1. Haematologica 2011, 96, 1302-1309. [CrossRef] 
59. Mandel, K.; Yang, Y.; Schambach, A.; Glage, S.; Otte, A.; Hass, R. Mesenchymal stem cells directly interact with breast cancer cells and promote tumor cell growth in vitro and in vivo. Stem Cells Dev. 2013, 22, 3114-3127. [CrossRef] [PubMed]

60. Syn, N.; Wang, L.; Sethi, G.; Thiery, J.P.; Goh, B.C. Exosome-Mediated Metastasis: From Epithelial-Mesenchymal Transition to Escape from Immunosurveillance. Trends Pharmacol. Sci. 2016, 37, 606-617. [CrossRef]

61. Shi, S.; Zhang, Q.; Xia, Y.; You, B.; Shan, Y.; Bao, L.; Li, L.; You, Y.; Gu, Z. Mesenchymal stem cell-derived exosomes facilitate nasopharyngeal carcinoma progression. Am. J. Cancer Res. 2016, 6, 459-472.

62. Meng, F.; Henson, R.; Wehbe-Janek, H.; Ghoshal, K.; Jacob, S.T.; Patel, T. MicroRNA-21 regulates expression of the PTEN tumor suppressor gene in human hepatocellular cancer. Gastroenterology 2007, 133, 647-658. [CrossRef]

63. Provenzano, P.P.; Inman, D.R.; Eliceiri, K.W.; Keely, P.J. Matrix density-induced mechanoregulation of breast cell phenotype, signaling and gene expression through a FAK-ERK linkage. Oncogene 2009, 28, 4326-4343. [CrossRef] [PubMed]

64. Narayanan, R.; Huang, C.C.; Ravindran, S. Hijacking the Cellular Mail: Exosome Mediated Differentiation of Mesenchymal Stem Cells. Stem Cells Int. 2016, 2016, 3808674. [CrossRef] [PubMed]

65. Cho, J.A.; Park, H.; Lim, E.H.; Lee, K.W. Exosomes from breast cancer cells can convert adipose tissue-derived mesenchymal stem cells into myofibroblast-like cells. Int. J. Oncol. 2012, 40, 130-138. [CrossRef]

66. Zhang, B.; Yin, Y.; Lai, R.C.; Tan, S.S.; Choo, A.B.; Lim, S.K. Mesenchymal stem cells secrete immunologically active exosomes. Stem Cells Dev. 2014, 23, 1233-1244. [CrossRef]

67. Mokarizadeh, A.; Delirezh, N.; Morshedi, A.; Mosayebi, G.; Farshid, A.A.; Mardani, K. Microvesicles derived from mesenchymal stem cells: Potent organelles for induction of tolerogenic signaling. Immunol. Lett. 2012, 147, 47-54. [CrossRef]

68. Del Fattore, A.; Luciano, R.; Pascucci, L.; Goffredo, B.M.; Giorda, E.; Scapaticci, M.; Fierabracci, A.; Muraca, M. Immunoregulatory Effects of Mesenchymal Stem Cell-Derived Extracellular Vesicles on T Lymphocytes. Cell Transplant. 2015, 24, 2615-2627. [CrossRef]

69. Phinney, D.G.; Di Giuseppe, M.; Njah, J.; Sala, E.; Shiva, S.; St Croix, C.M.; Stolz, D.B.; Watkins, S.C.; Di, Y.P.; Leikauf, G.D.; et al. Mesenchymal stem cells use extracellular vesicles to outsource mitophagy and shuttle microRNAs. Nat. Commun. 2015, 6, 8472. [CrossRef]

70. Conforti, A.; Scarsella, M.; Starc, N.; Giorda, E.; Biagini, S.; Proia, A.; Carsetti, R.; Locatelli, F.; Bernardo, M.E. Microvescicles derived from mesenchymal stromal cells are not as effective as their cellular counterpart in the ability to modulate immune responses in vitro. Stem Cells Dev. 2014, 23, 2591-2599. [CrossRef]

71. Chen, W.; Huang, Y.; Han, J.; Yu, L.; Li, Y.; Lu, Z.; Li, H.; Liu, Z.; Shi, C.; Duan, F.; et al. Immunomodulatory effects of mesenchymal stromal cells-derived exosome. Immunol. Res. 2016, 64, 831-840. [CrossRef]

72. Amarnath, S.; Foley, J.E.; Farthing, D.E.; Gress, R.E.; Laurence, A.; Eckhaus, M.A.; Metais, J.Y.; Rose, J.J.; Hakim, F.T.; Felizardo, T.C.; et al. Bone marrow-derived mesenchymal stromal cells harness purinergenic signaling to tolerize human Th1 cells in vivo. Stem Cells 2015, 33, 1200-1212. [CrossRef] [PubMed]

73. Ono, M.; Kosaka, N.; Tominaga, N.; Yoshioka, Y.; Takeshita, F.; Takahashi, R.U.; Yoshida, M.; Tsuda, H.; Tamura, K.; Ochiya, T. Exosomes from bone marrow mesenchymal stem cells contain a microRNA that promotes dormancy in metastatic breast cancer cells. Sci. Signal. 2014, 7, ra63. [CrossRef]

74. Ohyashiki, J.H.; Umezu, T.; Ohyashiki, K. Exosomes promote bone marrow angiogenesis in hematologic neoplasia: The role of hypoxia. Curr. Opin. Hematol. 2016, 23, 268-273. [CrossRef]

75. Allavena, P.; Sica, A.; Garlanda, C.; Mantovani, A. The Yin-Yang of tumor-associated macrophages in neoplastic progression and immune surveillance. Immunol. Rev. 2008, 222, 155-161. [CrossRef]

76. Chen, H.W.; Chen, H.Y.; Wang, L.T.; Wang, F.H.; Fang, L.W.; Lai, H.Y.; Chen, H.H.; Lu, J.; Hung, M.S.; Cheng, Y.; et al. Mesenchymal stem cells tune the development of monocyte-derived dendritic cells toward a myeloid-derived suppressive phenotype through growth-regulated oncogene chemokines. J. Immunol. 2013, 190, 5065-5077. [CrossRef] [PubMed]

77. Waterman, R.S.; Henkle, S.L.; Betancourt, A.M. Mesenchymal stem cell 1 (MSC1)-based therapy attenuates tumor growth whereas MSC2-treatment promotes tumor growth and metastasis. PLoS ONE 2012, 7, e45590. [CrossRef] [PubMed]

78. Egeblad, M.; Werb, Z. New functions for the matrix metalloproteinases in cancer progression. Nat. Rev. Cancer 2002, 2, 161-174. [CrossRef] [PubMed] 
79. Noe, V.; Fingleton, B.; Jacobs, K.; Crawford, H.C.; Vermeulen, S.; Steelant, W.; Bruyneel, E.; Matrisian, L.M.; Mareel, M. Release of an invasion promoter E-cadherin fragment by matrilysin and stromelysin-1. J. Cell Sci. 2001, 114, 111-118.

80. Rundhaug, J.E. Matrix metalloproteinases and angiogenesis. J. Cell. Mol. Med. 2005, 9, 267-285. [CrossRef] [PubMed]

81. Jiang, Y.; Goldberg, I.D.; Shi, Y.E. Complex roles of tissue inhibitors of metalloproteinases in cancer. Oncogene 2002, 21, 2245-2252. [CrossRef]

82. Wurtz, S.O.; Schrohl, A.S.; Sorensen, N.M.; Lademann, U.; Christensen, I.J.; Mouridsen, H.; Brunner, N. Tissue inhibitor of metalloproteinases-1 in breast cancer. Endocr. Relat. Cancer 2005, 12, 215-227. [CrossRef]

83. Jiang, X.; Dutton, C.M.; Qi, W.N.; Block, J.A.; Garamszegi, N.; Scully, S.P. siRNA mediated inhibition of MMP-1 reduces invasive potential of a human chondrosarcoma cell line. J. Cell. Physiol. 2005, 202, 723-730. [CrossRef]

84. Jones, J.L.; Walker, R.A. Control of matrix metalloproteinase activity in cancer. J. Pathol. 1997, 183, 377-379. [CrossRef]

85. Nakopoulou, L.; Panayotopoulou, E.G.; Giannopoulou, I.; Alexandrou, P.; Katsarou, S.; Athanassiadou, P.; Keramopoulos, A. Stromelysin-3 protein expression in invasive breast cancer: Relation to proliferation, cell survival and patients' outcome. Mod. Pathol. 2002, 15, 1154-1161. [CrossRef]

86. Vizoso, F.J.; Gonzalez, L.O.; Corte, M.D.; Rodriguez, J.C.; Vazquez, J.; Lamelas, M.L.; Junquera, S.; Merino, A.M.; Garcia-Muniz, J.L. Study of matrix metalloproteinases and their inhibitors in breast cancer. Br. J. Cancer 2007, 96, 903-911. [CrossRef]

87. Eiro, N.; Fernandez-Garcia, B.; Vazquez, J.; Del Casar, J.M.; Gonzalez, L.O.; Vizoso, F.J. A phenotype from tumor stroma based on the expression of metalloproteases and their inhibitors, associated with prognosis in breast cancer. Oncoimmunology 2015, 4, e992222. [CrossRef]

88. Eiró, N.; Fernandez-Garcia, B.; González, L.O.; Vizoso, F.J. Clinical Relevance of Matrix Metalloproteases and their Inhibitors in Breast Cancer. J. Carcinog. Mutagen. 2013, s13. [CrossRef]

89. Gonzalez, L.O.; Gonzalez-Reyes, S.; Marin, L.; Gonzalez, L.; Gonzalez, J.M.; Lamelas, M.L.; Merino, A.M.; Rodriguez, E.; Pidal, I.; del Casar, J.M.; et al. Comparative analysis and clinical value of the expression of metalloproteases and their inhibitors by intratumour stromal mononuclear inflammatory cells and those at the invasive front of breast carcinomas. Histopathology 2010, 57, 862-876. [CrossRef]

90. Del Casar, J.M.; Gonzalez, L.O.; Alvarez, E.; Junquera, S.; Marin, L.; Gonzalez, L.; Bongera, M.; Vazquez, J.; Vizoso, F.J. Comparative analysis and clinical value of the expression of metalloproteases and their inhibitors by intratumor stromal fibroblasts and those at the invasive front of breast carcinomas. Breast Cancer Res. Treat. 2009, 116, 39-52. [CrossRef]

91. Gonzalez, L.O.; Corte, M.D.; Junquera, S.; Gonzalez-Fernandez, R.; del Casar, J.M.; Garcia, C.; Andicoechea, A.; Vazquez, J.; Perez-Fernandez, R.; Vizoso, F.J. Expression and prognostic significance of metalloproteases and their inhibitors in luminal A and basal-like phenotypes of breast carcinoma. Hum. Pathol. 2009, 40, 1224-1233. [CrossRef]

92. Del Casar, J.M.; Gonzalez-Reyes, S.; Gonzalez, L.O.; Gonzalez, J.M.; Junquera, S.; Bongera, M.; Garcia, M.F.; Andicoechea, A.; Serra, C.; Vizoso, F.J. Expression of metalloproteases and their inhibitors in different histological types of breast cancer. J. Cancer Res. Clin. Oncol. 2010, 136, 811-819. [CrossRef] [PubMed]

93. Eiro, N.; Gonzalez, L.; Gonzalez, L.O.; Fernandez-Garcia, B.; Lamelas, M.L.; Marin, L.; Gonzalez-Reyes, S.; del Casar, J.M.; Vizoso, F.J. Relationship between the inflammatory molecular profile of breast carcinomas and distant metastasis development. PLoS ONE 2012, 7, e49047. [CrossRef] [PubMed]

94. Eiro, N.; Fernandez-Garcia, B.; Gonzalez, L.O.; Vizoso, F.J. Cytokines related to MMP-11 expression by inflammatory cells and breast cancer metastasis. Oncoimmunology 2013, 2, e24010. [CrossRef]

95. Manicone, A.M.; McGuire, J.K. Matrix metalloproteinases as modulators of inflammation. Semin. Cell Dev. Biol. 2008, 19, 34-41. [CrossRef]

96. Cid, S.; Eiro, N.; Gonzalez, L.O.; Beridze, N.; Vazquez, J.; Vizoso, F.J. Expression and Clinical Significance of Metalloproteases and Their Inhibitors by Endothelial Cells From Invasive Breast Carcinomas. Clin. Breast Cancer 2016, 16, e83-e91. [CrossRef] [PubMed]

97. Qi, J.H.; Ebrahem, Q.; Moore, N.; Murphy, G.; Claesson-Welsh, L.; Bond, M.; Baker, A.; Anand-Apte, B. A novel function for tissue inhibitor of metalloproteinases-3 (TIMP3): Inhibition of angiogenesis by blockage of VEGF binding to VEGF receptor-2. Nat. Med. 2003, 9, 407-415. [CrossRef] 
98. Cruz-Munoz, W.; Kim, I.; Khokha, R. TIMP-3 deficiency in the host, but not in the tumor, enhances tumor growth and angiogenesis. Oncogene 2006, 25, 650-655. [CrossRef]

99. Qi, J.H.; Anand-Apte, B. Tissue inhibitor of metalloproteinase-3 (TIMP3) promotes endothelial apoptosis via a caspase-independent mechanism. Apoptosis 2015, 20, 523-534. [CrossRef]

100. Zamarron, B.F.; Chen, W. Dual roles of immune cells and their factors in cancer development and progression. Int. J. Biol. Sci. 2011, 7, 651-658. [CrossRef]

101. Landskron, G.; De la Fuente, M.; Thuwajit, P.; Thuwajit, C.; Hermoso, M.A. Chronic inflammation and cytokines in the tumor microenvironment. J. Immunol. Res. 2014, 2014, 149185. [CrossRef]

102. Esquivel-Velazquez, M.; Ostoa-Saloma, P.; Palacios-Arreola, M.I.; Nava-Castro, K.E.; Castro, J.I.; Morales-Montor, J. The role of cytokines in breast cancer development and progression. J. Interferon Cytokine Res. 2015, 35, 1-16. [CrossRef]

103. Lin, S.; Gan, Z.; Han, K.; Yao, Y.; Min, D. Interleukin-6 as a prognostic marker for breast cancer: A meta-analysis. Tumori 2015, 101, 535-541. [CrossRef] [PubMed]

104. Tripsianis, G.; Papadopoulou, E.; Anagnostopoulos, K.; Botaitis, S.; Katotomichelakis, M.; Romanidis, K.; Kontomanolis, E.; Tentes, I.; Kortsaris, A. Coexpression of IL-6 and TNF-alpha: Prognostic significance on breast cancer outcome. Neoplasma 2014, 61, 205-212. [CrossRef] [PubMed]

105. Fernandez-Garcia, B.; Eiro, N.; Miranda, M.A.; Cid, S.; Gonzalez, L.O.; Dominguez, F.; Vizoso, F.J. Prognostic significance of inflammatory factors expression by stroma from breast carcinomas. Carcinogenesis 2016, 37, 768-776. [CrossRef] [PubMed]

106. Hamidullah; Changkija, B.; Konwar, R. Role of interleukin-10 in breast cancer. Breast Cancer Res. Treat. 2012, 133, 11-21. [CrossRef]

107. Murugaiyan, G.; Saha, B. Protumor vs antitumor functions of IL-17. J. Immunol. 2009, 183, 4169-4175. [CrossRef]

108. Martin-Orozco, N.; Muranski, P.; Chung, Y.; Yang, X.O.; Yamazaki, T.; Lu, S.; Hwu, P.; Restifo, N.P.; Overwijk, W.W.; Dong, C. T helper 17 cells promote cytotoxic T cell activation in tumor immunity. Immunity 2009, 31, 787-798. [CrossRef]

109. Karczewska, A.; Nawrocki, S.; Breborowicz, D.; Filas, V.; Mackiewicz, A. Expression of interleukin-6, interleukin-6 receptor, and glycoprotein 130 correlates with good prognoses for patients with breast carcinoma. Cancer 2000, 88, 2061-2071. [CrossRef]

110. Benchetrit, F.; Ciree, A.; Vives, V.; Warnier, G.; Gey, A.; Sautes-Fridman, C.; Fossiez, F.; Haicheur, N.; Fridman, W.H.; Tartour, E. Interleukin-17 inhibits tumor cell growth by means of a T-cell-dependent mechanism. Blood 2002, 99, 2114-2121. [CrossRef]

111. Kawai, T.; Akira, S. TLR signaling. Cell Death Differ. 2006, 13, 816-825. [CrossRef]

112. Sato, Y.; Goto, Y.; Narita, N.; Hoon, D.S. Cancer Cells Expressing Toll-like Receptors and the Tumor Microenvironment. Cancer Microenviron. 2009, 2 (Suppl. S1), 205-214. [CrossRef]

113. Huang, B.; Zhao, J.; Unkeless, J.C.; Feng, Z.H.; Xiong, H. TLR signaling by tumor and immune cells: A double-edged sword. Oncogene 2008, 27, 218-224. [CrossRef]

114. Rakoff-Nahoum, S.; Medzhitov, R. Role of toll-like receptors in tissue repair and tumorigenesis. Biochemistry 2008, 73, 555-561. [CrossRef]

115. Gonzalez-Reyes, S.; Marin, L.; Gonzalez, L.; Gonzalez, L.O.; del Casar, J.M.; Lamelas, M.L.; Gonzalez-Quintana, J.M.; Vizoso, F.J. Study of TLR3, TLR4 and TLR9 in breast carcinomas and their association with metastasis. BMC Cancer 2010, 10, 665. [CrossRef]

116. Murad, Y.M.; Clay, T.M.; Lyerly, H.K.; Morse, M.A. CPG-7909 (PF-3512676, ProMune): Toll-like receptor-9 agonist in cancer therapy. Expert Opin. Biol. Ther. 2007, 7, 1257-1266. [CrossRef]

117. Sagiv-Barfi, I.; Czerwinski, D.K.; Levy, S.; Alam, I.S.; Mayer, A.T.; Gambhir, S.S.; Levy, R. Eradication of spontaneous malignancy by local immunotherapy. Sci. Transl. Med. 2018, 10. [CrossRef]

118. Lambert, A.W.; Ozturk, S.; Thiagalingam, S. Integrin signaling in mammary epithelial cells and breast cancer. ISRN Oncol. 2012, 2012, 493283. [CrossRef]

119. Campbell, I.D.; Humphries, M.J. Integrin structure, activation, and interactions. Cold Spring Harb. Perspect. Biol. 2011, 3. [CrossRef]

120. Mousa, S.A. Cell adhesion molecules: Potential therapeutic \& diagnostic implications. Mol. Biotechnol. 2008, 38, 33-40. [CrossRef] 
121. Calderwood, D.A.; Campbell, I.D.; Critchley, D.R. Talins and kindlins: Partners in integrin-mediated adhesion. Nat. Rev. Mol. Cell Biol. 2013, 14, 503-517. [CrossRef]

122. Desgrosellier, J.S.; Cheresh, D.A. Integrins in cancer: Biological implications and therapeutic opportunities. Nat. Rev. Cancer 2010, 10, 9-22. [CrossRef]

123. Legate, K.R.; Montanez, E.; Kudlacek, O.; Fassler, R. ILK, PINCH and parvin: The tIPP of integrin signalling. Nat. Rev. Mol. Cell Biol. 2006, 7, 20-31. [CrossRef]

124. Hynes, R.O. Integrins: Bidirectional, allosteric signaling machines. Cell 2002, 110, 673-687. [CrossRef]

125. Bianconi, D.; Unseld, M.; Prager, G.W. Integrins in the Spotlight of Cancer. Int. J. Mol. Sci. 2016, $17,2037$. [CrossRef]

126. Winograd-Katz, S.E.; Fassler, R.; Geiger, B.; Legate, K.R. The integrin adhesome: From genes and proteins to human disease. Nat. Rev. Mol. Cell Biol. 2014, 15, 273-288. [CrossRef]

127. Hanahan, D.; Weinberg, R.A. Hallmarks of cancer: The next generation. Cell 2011, 144, 646-674. [CrossRef]

128. Yuan, Y.; Jiang, Y.C.; Sun, C.K.; Chen, Q.M. Role of the tumor microenvironment in tumor progression and the clinical applications (Review). Oncol. Rep. 2016, 35, 2499-2515. [CrossRef]

129. Derbal, Y. Perspective on the dynamics of cancer. Theor. Biol. Med. Model. 2017, 14, 18. [CrossRef]

130. Gandellini, P.; Andriani, F.; Merlino, G.; D’Aiuto, F.; Roz, L.; Callari, M. Complexity in the tumour microenvironment: Cancer associated fibroblast gene expression patterns identify both common and unique features of tumour-stroma crosstalk across cancer types. Semin. Cancer Biol. 2015, 35, 96-106. [CrossRef]

131. Harper, J.; Sainson, R.C. Regulation of the anti-tumour immune response by cancer-associated fibroblasts. Semin. Cancer Biol. 2014, 25, 69-77. [CrossRef]

132. Popivanova, B.K.; Kostadinova, F.I.; Furuichi, K.; Shamekh, M.M.; Kondo, T.; Wada, T.; Egashira, K.; Mukaida, N. Blockade of a chemokine, CCL2, reduces chronic colitis-associated carcinogenesis in mice. Cancer Res. 2009, 69, 7884-7892. [CrossRef]

133. Roca, H.; Varsos, Z.S.; Sud, S.; Craig, M.J.; Ying, C.; Pienta, K.J. CCL2 and interleukin-6 promote survival of human CD11b+ peripheral blood mononuclear cells and induce M2-type macrophage polarization. J. Biol. Chem. 2009, 284, 34342-34354. [CrossRef]

134. Sumimoto, H.; Imabayashi, F.; Iwata, T.; Kawakami, Y. The BRAF-MAPK signaling pathway is essential for cancer-immune evasion in human melanoma cells. J. Exp. Med. 2006, 203, 1651-1656. [CrossRef]

135. Shchors, K.; Shchors, E.; Rostker, F.; Lawlor, E.R.; Brown-Swigart, L.; Evan, G.I. The Myc-dependent angiogenic switch in tumors is mediated by interleukin 1beta. Genes Dev. 2006, 20, 2527-2538. [CrossRef]

136. Eiro, N.; Gonzalez, L.; Martinez-Ordonez, A.; Fernandez-Garcia, B.; Gonzalez, L.O.; Cid, S.; Dominguez, F.; Perez-Fernandez, R.; Vizoso, F.J. Cancer-associated fibroblasts affect breast cancer cell gene expression, invasion and angiogenesis. Cell. Oncol. 2018, 41, 369-378. [CrossRef]

137. Cocucci, E.; Meldolesi, J. Ectosomes and exosomes: Shedding the confusion between extracellular vesicles. Trends Cell Biol. 2015, 25, 364-372. [CrossRef]

138. Abels, E.R.; Breakefield, X.O. Introduction to Extracellular Vesicles: Biogenesis, RNA Cargo Selection, Content, Release, and Uptake. Cell. Mol. Neurobiol. 2016, 36, 301-312. [CrossRef]

139. Boyiadzis, M.; Whiteside, T.L. The emerging roles of tumor-derived exosomes in hematological malignancies. Leukemia 2017, 31, 1259-1268. [CrossRef]

140. Muller, L.; Mitsuhashi, M.; Simms, P.; Gooding, W.E.; Whiteside, T.L. Tumor-derived exosomes regulate expression of immune function-related genes in human T cell subsets. Sci. Rep. 2016, 6, 20254. [CrossRef]

141. Muller, L.; Simms, P.; Hong, C.S.; Nishimura, M.I.; Jackson, E.K.; Watkins, S.C.; Whiteside, T.L. Human tumor-derived exosomes (TEX) regulate Treg functions via cell surface signaling rather than uptake mechanisms. Oncoimmunology 2017, 6, e1261243. [CrossRef] [PubMed]

142. Mulcahy, L.A.; Pink, R.C.; Carter, D.R. Routes and mechanisms of extracellular vesicle uptake. J. Extracell. Vesicles 2014, 3. [CrossRef]

143. Ludwig, S.; Floros, T.; Theodoraki, M.N.; Hong, C.S.; Jackson, E.K.; Lang, S.; Whiteside, T.L. Suppression of Lymphocyte Functions by Plasma Exosomes Correlates with Disease Activity in Patients with Head and Neck Cancer. Clin. Cancer Res. 2017, 23, 4843-4854. [CrossRef]

144. Hong, C.S.; Funk, S.; Muller, L.; Boyiadzis, M.; Whiteside, T.L. Isolation of biologically active and morphologically intact exosomes from plasma of patients with cancer. J. Extracell. Vesicles 2016, 5, 29289. [CrossRef] [PubMed] 
145. Boyiadzis, M.; Whiteside, T.L. Information transfer by exosomes: A new frontier in hematologic malignancies. Blood Rev. 2015, 29, 281-290. [CrossRef] [PubMed]

146. Whiteside, T.L. Exosomes carrying immunoinhibitory proteins and their role in cancer. Clin. Exp. Immunol. 2017, 189, 259-267. [CrossRef] [PubMed]

147. Di Trapani, M.; Bassi, G.; Midolo, M.; Gatti, A.; Kamga, P.T.; Cassaro, A.; Carusone, R.; Adamo, A.; Krampera, M. Differential and transferable modulatory effects of mesenchymal stromal cell-derived extracellular vesicles on T, B and NK cell functions. Sci. Rep. 2016, 6, 24120. [CrossRef] [PubMed]

148. Marote, A.; Teixeira, F.G.; Mendes-Pinheiro, B.; Salgado, A.J. MSCs-Derived Exosomes: Cell-Secreted Nanovesicles with Regenerative Potential. Front. Pharmacol. 2016, 7, 231. [CrossRef]

149. Lener, T.; Gimona, M.; Aigner, L.; Borger, V.; Buzas, E.; Camussi, G.; Chaput, N.; Chatterjee, D.; Court, F.A.; Del Portillo, H.A.; et al. Applying extracellular vesicles based therapeutics in clinical trials-An ISEV position paper. J. Extracell. Vesicles 2015, 4, 30087. [CrossRef]

150. Burnstock, G.; Di Virgilio, F. Purinergic signalling and cancer. Purinergic Signal. 2013, 9, 491-540. [CrossRef]

151. Lai, R.C.; Tan, S.S.; Teh, B.J.; Sze, S.K.; Arslan, F.; de Kleijn, D.P.; Choo, A.; Lim, S.K. Proteolytic Potential of the MSC Exosome Proteome: Implications for an Exosome-Mediated Delivery of Therapeutic Proteasome. Int. J. Proteom. 2012, 2012, 971907. [CrossRef]

152. Chen, T.S.; Lai, R.C.; Lee, M.M.; Choo, A.B.; Lee, C.N.; Lim, S.K. Mesenchymal stem cell secretes microparticles enriched in pre-microRNAs. Nucleic Acids Res. 2010, 38, 215-224. [CrossRef]

153. Whiteside, T.L. Exosome and mesenchymal stem cell cross-talk in the tumor microenvironment. Semin. Immunol. 2018, 35, 69-79. [CrossRef] [PubMed]

154. Dostert, G.; Mesure, B.; Menu, P.; Velot, E. How Do Mesenchymal Stem Cells Influence or Are Influenced by Microenvironment through Extracellular Vesicles Communication? Front. Cell Dev. Biol. 2017, 5, 6. [CrossRef]

155. Sharma, A. Bioinformatic analysis revealing association of exosomal mRNAs and proteins in epigenetic inheritance. J. Theor. Biol. 2014, 357, 143-149. [CrossRef]

156. Lindoso, R.S.; Collino, F.; Camussi, G. Extracellular vesicles derived from renal cancer stem cells induce a pro-tumorigenic phenotype in mesenchymal stromal cells. Oncotarget 2015, 6, 7959-7969. [CrossRef]

157. Seguin, L.; Desgrosellier, J.S.; Weis, S.M.; Cheresh, D.A. Integrins and cancer: Regulators of cancer stemness, metastasis, and drug resistance. Trends Cell Biol. 2015, 25, 234-240. [CrossRef] [PubMed]

158. Hamidi, H.; Pietila, M.; Ivaska, J. The complexity of integrins in cancer and new scopes for therapeutic targeting. Br. J. Cancer 2016, 115, 1017-1023. [CrossRef]

159. Guo, W.; Giancotti, F.G. Integrin signalling during tumour progression. Nat. Rev. Mol. Cell Biol. 2004, 5, 816-826. [CrossRef]

160. Hehlgans, S.; Haase, M.; Cordes, N. Signalling via integrins: Implications for cell survival and anticancer strategies. Biochim. Biophys. Acta 2007, 1775, 163-180. [CrossRef]

161. Kuphal, S.; Bauer, R.; Bosserhoff, A.K. Integrin signaling in malignant melanoma. Cancer Metastasis Rev. 2005, 24, 195-222. [CrossRef] [PubMed]

162. Glukhova, M.A.; Streuli, C.H. How integrins control breast biology. Curr. Opin. Cell Biol. 2013, $25,633-641$. [CrossRef] [PubMed]

163. Hamidi, H.; Ivaska, J. Every step of the way: Integrins in cancer progression and metastasis. Nat. Rev. Cancer 2018, 18, 533-548. [CrossRef] [PubMed]

164. Cagnet, S.; Faraldo, M.M.; Kreft, M.; Sonnenberg, A.; Raymond, K.; Glukhova, M.A. Signaling events mediated by alpha3beta1 integrin are essential for mammary tumorigenesis. Oncogene 2014, 33, 4286-4295. [CrossRef]

165. White, D.E.; Kurpios, N.A.; Zuo, D.; Hassell, J.A.; Blaess, S.; Mueller, U.; Muller, W.J. Targeted disruption of beta1-integrin in a transgenic mouse model of human breast cancer reveals an essential role in mammary tumor induction. Cancer Cell 2004, 6, 159-170. [CrossRef] [PubMed]

166. Stoletov, K.; Kato, H.; Zardouzian, E.; Kelber, J.; Yang, J.; Shattil, S.; Klemke, R. Visualizing extravasation dynamics of metastatic tumor cells. J. Cell Sci. 2010, 123, 2332-2341. [CrossRef]

167. Dos Santos, P.B.; Zanetti, J.S.; Ribeiro-Silva, A.; Beltrao, E.I. Beta 1 integrin predicts survival in breast cancer: A clinicopathological and immunohistochemical study. Diagn. Pathol. 2012, 7, 104. [CrossRef]

168. Jahangiri, A.; Aghi, M.K.; Carbonell, W.S. beta1 integrin: Critical path to antiangiogenic therapy resistance and beyond. Cancer Res. 2014, 74, 3-7. [CrossRef] [PubMed] 
169. Sun, Q.; Zhou, C.; Ma, R.; Guo, Q.; Huang, H.; Hao, J.; Liu, H.; Shi, R.; Liu, B. Prognostic value of increased integrin-beta 1 expression in solid cancers: A meta-analysis. OncoTargets Ther. 2018, 11, 1787-1799. [CrossRef]

170. Friedrichs, K.; Ruiz, P.; Franke, F.; Gille, I.; Terpe, H.J.; Imhof, B.A. High expression level of alpha 6 integrin in human breast carcinoma is correlated with reduced survival. Cancer Res. 1995, 55, 901-906.

171. Hu, T.; Zhou, R.; Zhao, Y.; Wu, G. Integrin alpha6/Akt/Erk signaling is essential for human breast cancer resistance to radiotherapy. Sci. Rep. 2016, 6, 33376. [CrossRef] [PubMed]

172. Huck, L.; Pontier, S.M.; Zuo, D.M.; Muller, W.J. beta1-integrin is dispensable for the induction of ErbB2 mammary tumors but plays a critical role in the metastatic phase of tumor progression. Proc. Natl. Acad. Sci. USA 2010, 107, 15559-15564. [CrossRef] [PubMed]

173. Ramirez, N.E.; Zhang, Z.; Madamanchi, A.; Boyd, K.L.; O’Rear, L.D.; Nashabi, A.; Li, Z.; Dupont, W.D.; Zijlstra, A.; Zutter, M.M. The alpha(2)beta(1) integrin is a metastasis suppressor in mouse models and human cancer. J. Clin. Investig. 2011, 121, 226-237. [CrossRef] [PubMed]

174. Lanzafame, S.; Emmanuele, C.; Torrisi, A. Correlation of alpha 2 beta 1 integrin expression with histological type and hormonal receptor status in breast carcinomas. Pathol. Res. Pract. 1996, 192, 1031-1038. [CrossRef]

175. Gonzalez, M.A.; Pinder, S.E.; Wencyk, P.M.; Bell, J.A.; Elston, C.W.; Nicholson, R.I.; Robertson, J.F.; Blamey, R.W.; Ellis, I.O. An immunohistochemical examination of the expression of E-cadherin, alpha- and beta/gamma-catenins, and alpha2- and beta1-integrins in invasive breast cancer. J. Pathol. 1999, 187, 523-529. [CrossRef]

176. Petricevic, B.; Vrbanec, D.; Jakic-Razumovic, J.; Brcic, I.; Rabic, D.; Badovinac, T.; Ozimec, E.; Bali, V. Expression of Toll-like receptor 4 and beta 1 integrin in breast cancer. Med. Oncol. 2012, 29, 486-494. [CrossRef] [PubMed]

177. Berry, M.G.; Gui, G.P.; Wells, C.A.; Carpenter, R. Integrin expression and survival in human breast cancer. Eur. J. Surg. Oncol. 2004, 30, 484-489. [CrossRef]

178. Attieh, Y.; Clark, A.G.; Grass, C.; Richon, S.; Pocard, M.; Mariani, P.; Elkhatib, N.; Betz, T.; Gurchenkov, B.; Vignjevic, D.M. Cancer-associated fibroblasts lead tumor invasion through integrin-beta3-dependent fibronectin assembly. J. Cell Biol. 2017, 216, 3509-3520. [CrossRef]

179. Cavaco, A.C.M.; Rezaei, M.; Caliandro, M.F.; Lima, A.M.; Stehling, M.; Dhayat, S.A.; Haier, J.; Brakebusch, C.; Eble, J.A. The Interaction between Laminin-332 and alpha3beta1 Integrin Determines Differentiation and Maintenance of CAFs, and Supports Invasion of Pancreatic Duct Adenocarcinoma Cells. Cancers 2018, 11, 14. [CrossRef]

180. Erdogan, B.; Ao, M.; White, L.M.; Means, A.L.; Brewer, B.M.; Yang, L.; Washington, M.K.; Shi, C.; Franco, O.E.; Weaver, A.M.; et al. Cancer-associated fibroblasts promote directional cancer cell migration by aligning fibronectin. J. Cell Biol. 2017, 216, 3799-3816. [CrossRef]

181. Pontiggia, O.; Sampayo, R.; Raffo, D.; Motter, A.; Xu, R.; Bissell, M.J.; Joffe, E.B.; Simian, M. The tumor microenvironment modulates tamoxifen resistance in breast cancer: A role for soluble stromal factors and fibronectin through beta1 integrin. Breast Cancer Res. Treat. 2012, 133, 459-471. [CrossRef]

182. Dittmer, A.; Dittmer, J. Long-term exposure to carcinoma-associated fibroblasts makes breast cancer cells addictive to integrin beta1. Oncotarget 2018, 9, 22079-22094. [CrossRef]

183. Zhou, W.; Ke, S.Q.; Huang, Z.; Flavahan, W.; Fang, X.; Paul, J.; Wu, L.; Sloan, A.E.; McLendon, R.E.; Li, X.; et al. Periostin secreted by glioblastoma stem cells recruits M2 tumour-associated macrophages and promotes malignant growth. Nat. Cell Biol. 2015, 17, 170-182. [CrossRef]

184. Kale, S.; Raja, R.; Thorat, D.; Soundararajan, G.; Patil, T.V.; Kundu, G.C. Osteopontin signaling upregulates cyclooxygenase-2 expression in tumor-associated macrophages leading to enhanced angiogenesis and melanoma growth via alpha9beta1 integrin. Oncogene 2014, 33, 2295-2306. [CrossRef]

185. Yakubenko, V.P.; Lobb, R.R.; Plow, E.F.; Ugarova, T.P. Differential induction of gelatinase B (MMP-9) and gelatinase A (MMP-2) in T lymphocytes upon alpha(4)beta(1)-mediated adhesion to VCAM-1 and the CS-1 peptide of fibronectin. Exp. Cell Res. 2000, 260, 73-84. [CrossRef]

186. Bank, I.; Book, M.; Ware, R. Functional role of VLA-1 (CD49A) in adhesion, cation-dependent spreading, and activation of cultured human T lymphocytes. Cell. Immunol. 1994, 156, 424-437. [CrossRef]

187. Park, E.J.; Peixoto, A.; Imai, Y.; Goodarzi, A.; Cheng, G.; Carman, C.V.; von Andrian, U.H.; Shimaoka, M. Distinct roles for LFA-1 affinity regulation during T-cell adhesion, diapedesis, and interstitial migration in lymph nodes. Blood 2010, 115, 1572-1581. [CrossRef] 
188. Bertoni, A.; Alabiso, O.; Galetto, A.S.; Baldanzi, G. Integrins in T Cell Physiology. Int. J. Mol. Sci. 2018, 19, 485. [CrossRef]

189. Holash, J.; Maisonpierre, P.C.; Compton, D.; Boland, P.; Alexander, C.R.; Zagzag, D.; Yancopoulos, G.D.; Wiegand, S.J. Vessel cooption, regression, and growth in tumors mediated by angiopoietins and VEGF. Science 1999, 284, 1994-1998. [CrossRef]

190. Munshi, H.G.; Stack, M.S. Reciprocal interactions between adhesion receptor signaling and MMP regulation. Cancer Metastasis Rev. 2006, 25, 45-56. [CrossRef]

191. Silletti, S.; Kessler, T.; Goldberg, J.; Boger, D.L.; Cheresh, D.A. Disruption of matrix metalloproteinase 2 binding to integrin alpha vbeta 3 by an organic molecule inhibits angiogenesis and tumor growth in vivo. Proc. Natl. Acad. Sci. USA 2001, 98, 119-124. [CrossRef]

192. Rolli, M.; Fransvea, E.; Pilch, J.; Saven, A.; Felding-Habermann, B. Activated integrin alphavbeta3 cooperates with metalloproteinase MMP-9 in regulating migration of metastatic breast cancer cells. Proc. Natl. Acad. Sci. USA 2003, 100, 9482-9487. [CrossRef]

193. Nisato, R.E.; Hosseini, G.; Sirrenberg, C.; Butler, G.S.; Crabbe, T.; Docherty, A.J.; Wiesner, M.; Murphy, G.; Overall, C.M.; Goodman, S.L.; et al. Dissecting the role of matrix metalloproteinases (MMP) and integrin alpha(v)beta3 in angiogenesis in vitro: Absence of hemopexin C domain bioactivity, but membrane-Type 1-MMP and alpha(v)beta3 are critical. Cancer Res. 2005, 65, 9377-9387. [CrossRef]

194. Moritz, M.N.O.; Eustaquio, L.M.S.; Micocci, K.C.; Nunes, A.C.C.; Dos Santos, P.K.; de Castro Vieira, T.; Selistre-de-Araujo, H.S. Alternagin-C binding to alpha2beta1 integrin controls matrix metalloprotease-9 and matrix metalloprotease-2 in breast tumor cells and endothelial cells. J. Venom. Anim. Toxins Incl. Trop. Dis. 2018, 24, 13. [CrossRef]

195. Bjorklund, M.; Heikkila, P.; Koivunen, E. Peptide inhibition of catalytic and noncatalytic activities of matrix metalloproteinase-9 blocks tumor cell migration and invasion. J. Biol. Chem. 2004, 279, 29589-29597. [CrossRef]

196. Barkan, D.; Kleinman, H.; Simmons, J.L.; Asmussen, H.; Kamaraju, A.K.; Hoenorhoff, M.J.; Liu, Z.Y.; Costes, S.V.; Cho, E.H.; Lockett, S.; et al. Inhibition of metastatic outgrowth from single dormant tumor cells by targeting the cytoskeleton. Cancer Res. 2008, 68, 6241-6250. [CrossRef]

197. Shibue, T.; Weinberg, R.A. Integrin beta1-focal adhesion kinase signaling directs the proliferation of metastatic cancer cells disseminated in the lungs. Proc. Natl. Acad. Sci. USA 2009, 106, 10290-10295. [CrossRef]

198. Wu, P.H.; Onodera, Y.; Ichikawa, Y.; Rankin, E.B.; Giaccia, A.J.; Watanabe, Y.; Qian, W.; Hashimoto, T.; Shirato, H.; Nam, J.M. Targeting integrins with RGD-conjugated gold nanoparticles in radiotherapy decreases the invasive activity of breast cancer cells. Int. J. Nanomed. 2017, 12, 5069-5085. [CrossRef]

199. Nam, J.M.; Ahmed, K.M.; Costes, S.; Zhang, H.; Onodera, Y.; Olshen, A.B.; Hatanaka, K.C.; Kinoshita, R.; Ishikawa, M.; Sabe, H.; et al. beta1-Integrin via NF-kappaB signaling is essential for acquisition of invasiveness in a model of radiation treated in situ breast cancer. Breast Cancer Res. 2013, 15, R60. [CrossRef]

200. Peinado, H.; Zhang, H.; Matei, I.R.; Costa-Silva, B.; Hoshino, A.; Rodrigues, G.; Psaila, B.; Kaplan, R.N.; Bromberg, J.F.; Kang, Y.; et al. Pre-metastatic niches: Organ-specific homes for metastases. Nat. Rev. Cancer 2017, 17, 302-317. [CrossRef]

201. Paget, S. The distribution of secondary growths in cancer of the breast. 1889. Cancer Metastasis Rev. 1989, 8, 98-101. [PubMed]

202. Prada, I.; Meldolesi, J. Binding and Fusion of Extracellular Vesicles to the Plasma Membrane of Their Cell Targets. Int. J. Mol. Sci. 2016, 17, 1296. [CrossRef] [PubMed]

203. Hoshino, A.; Costa-Silva, B.; Shen, T.L.; Rodrigues, G.; Hashimoto, A.; Tesic Mark, M.; Molina, H.; Kohsaka, S.; Di Giannatale, A.; Ceder, S.; et al. Tumour exosome integrins determine organotropic metastasis. Nature 2015, 527, 329-335. [CrossRef] [PubMed]

204. Alderton, G.K. Metastasis: Directions to metastatic sites. Nat. Rev. Cancer 2015, 15, 696-697. [CrossRef] [PubMed]

205. Paolillo, M.; Schinelli, S. Integrins and Exosomes, a Dangerous Liaison in Cancer Progression. Cancers 2017, 9, 95. [CrossRef]

206. Kristensen, T.B.; Knutsson, M.L.; Wehland, M.; Laursen, B.E.; Grimm, D.; Warnke, E.; Magnusson, N.E. Anti-vascular endothelial growth factor therapy in breast cancer. Int. J. Mol. Sci. 2014, 15, 23024-23041. [CrossRef] 
207. Sun, Y. Translational horizons in the tumor microenvironment: Harnessing breakthroughs and targeting cures. Med. Res. Rev. 2015, 35, 408-436. [CrossRef] [PubMed]

208. Slany, A.; Bileck, A.; Muqaku, B.; Gerner, C. Targeting breast cancer-associated fibroblasts to improve anti-cancer therapy. Breast 2015, 24, 532-538. [CrossRef] [PubMed]

209. Correia, A.L.; Bissell, M.J. The tumor microenvironment is a dominant force in multidrug resistance. Drug Resist. Updat. 2012, 15, 39-49. [CrossRef]

210. Kerbel, R.S. A cancer therapy resistant to resistance. Nature 1997, 390, 335-336. [CrossRef] [PubMed]

211. Tuder, R.M.; Lara, A.R.; Thannickal, V.J. Lactate, a novel trigger of transforming growth factor-beta activation in idiopathic pulmonary fibrosis. Am. J. Respir. Crit. Care Med. 2012, 186, 701-703. [CrossRef]

212. Zhang, J.; Liu, J. Tumor stroma as targets for cancer therapy. Pharmacol. Ther. 2013, 137, 200-215. [CrossRef]

213. Khan, G.J.; Sun, L.; Khan, S.; Yuan, S.; Nongyue, H. Versatility of Cancer Associated Fibroblasts: Commendable Targets for Anti-tumor Therapy. Curr. Drug Targets 2018, 19, 1573-1588. [CrossRef]

214. Dorff, T.B.; Goldman, B.; Pinski, J.K.; Mack, P.C.; Lara, P.N., Jr.; Van Veldhuizen, P.J., Jr.; Quinn, D.I.; Vogelzang, N.J.; Thompson, I.M., Jr.; Hussain, M.H. Clinical and correlative results of SWOG S0354: A phase II trial of CNTO328 (siltuximab), a monoclonal antibody against interleukin-6, in chemotherapy-pretreated patients with castration-resistant prostate cancer. Clin. Cancer Res. 2010, 16, 3028-3034. [CrossRef]

215. Alas, S.; Emmanouilides, C.; Bonavida, B. Inhibition of interleukin 10 by rituximab results in down-regulation of bcl-2 and sensitization of B-cell non-Hodgkin's lymphoma to apoptosis. Clin. Cancer Res. 2001, 7, 709-723.

216. Migali, C.; Milano, M.; Trapani, D.; Criscitiello, C.; Esposito, A.; Locatelli, M.; Minchella, I.; Curigliano, G. Strategies to modulate the immune system in breast cancer: Checkpoint inhibitors and beyond. Ther. Adv. Med. Oncol. 2016, 8, 360-374. [CrossRef]

217. Maffey, A.; Storini, C.; Diceglie, C.; Martelli, C.; Sironi, L.; Calzarossa, C.; Tonna, N.; Lovchik, R.; Delamarche, E.; Ottobrini, L.; et al. Mesenchymal stem cells from tumor microenvironment favour breast cancer stem cell proliferation, cancerogenic and metastatic potential, via ionotropic purinergic signalling. Sci. Rep. 2017, 7, 13162. [CrossRef]

218. Klopp, A.H.; Gupta, A.; Spaeth, E.; Andreeff, M.; Marini, F., 3rd. Concise review: Dissecting a discrepancy in the literature: Do mesenchymal stem cells support or suppress tumor growth? Stem Cells 2011, 29, 11-19. [CrossRef]

219. Attar-Schneider, O.; Zismanov, V.; Drucker, L.; Gottfried, M. Secretome of human bone marrow mesenchymal stem cells: An emerging player in lung cancer progression and mechanisms of translation initiation. Tumor Biol. 2016, 37, 4755-4765. [CrossRef]

220. Marcus, H.; Attar-Schneider, O.; Dabbah, M.; Zismanov, V.; Tartakover-Matalon, S.; Lishner, M.; Drucker, L. Mesenchymal stem cells secretomes' affect multiple myeloma translation initiation. Cell. Signal. 2016, 28, 620-630. [CrossRef]

221. Onzi, G.R.; Ledur, P.F.; Hainzenreder, L.D.; Bertoni, A.P.; Silva, A.O.; Lenz, G.; Wink, M.R. Analysis of the safety of mesenchymal stromal cells secretome for glioblastoma treatment. Cytotherapy 2016, 18, 828-837. [CrossRef]

222. Eiro, N.; Sendon-Lago, J.; Seoane, S.; Bermudez, M.A.; Lamelas, M.L.; Garcia-Caballero, T.; Schneider, J.; Perez-Fernandez, R.; Vizoso, F.J. Potential therapeutic effect of the secretome from human uterine cervical stem cells against both cancer and stromal cells compared with adipose tissue stem cells. Oncotarget 2014, 5, 10692-10708. [CrossRef]

223. Karnoub, A.E.; Dash, A.B.; Vo, A.P.; Sullivan, A.; Brooks, M.W.; Bell, G.W.; Richardson, A.L.; Polyak, K.; Tubo, R.; Weinberg, R.A. Mesenchymal stem cells within tumour stroma promote breast cancer metastasis. Nature 2007, 449, 557-563. [CrossRef]

224. Muehlberg, F.L.; Song, Y.H.; Krohn, A.; Pinilla, S.P.; Droll, L.H.; Leng, X.; Seidensticker, M.; Ricke, J.; Altman, A.M.; Devarajan, E.; et al. Tissue-resident stem cells promote breast cancer growth and metastasis. Carcinogenesis 2009, 30, 589-597. [CrossRef]

225. Galie, M.; Konstantinidou, G.; Peroni, D.; Scambi, I.; Marchini, C.; Lisi, V.; Krampera, M.; Magnani, P.; Merigo, F.; Montani, M.; et al. Mesenchymal stem cells share molecular signature with mesenchymal tumor cells and favor early tumor growth in syngeneic mice. Oncogene 2008, 27, 2542-2551. [CrossRef]

226. Vizoso, F.J.; Eiro, N.; Cid, S.; Schneider, J.; Perez-Fernandez, R. Mesenchymal Stem Cell Secretome: Toward Cell-Free Therapeutic Strategies in Regenerative Medicine. Int. J. Mol. Sci. 2017, 18, 1852. [CrossRef] [PubMed] 
227. Schneider, J.; Eiro, N.; Perez-Fernandez, R.; Martinez-Ordonez, A.; Vizoso, F. Human Uterine Cervical Stromal Stem Cells (hUCESCs): Why and How they Exert their Antitumor Activity. Cancer Genom. Proteom. 2016, 13, 331-337.

228. Curley, G.P.; Blum, H.; Humphries, M.J. Integrin antagonists. Cell Mol. Life Sci. 1999, 56, 427-441. [CrossRef] [PubMed]

229. Raab-Westphal, S.; Marshall, J.F.; Goodman, S.L. Integrins as Therapeutic Targets: Successes and Cancers. Cancers 2017, 9, 110. [CrossRef] [PubMed] article distributed under the terms and conditions of the Creative Commons Attribution (CC BY) license (http://creativecommons.org/licenses/by/4.0/). 